\title{
Altered DNA methylation pattern characterizes the peripheral immune cells of patients with autoimmune hepatitis
}

Kalliopi Zachou ${ }^{1,2^{*}}$, Pinelopi Arvaniti ${ }^{{ }^{*}}$, Aggeliki Lyberopoulou ${ }^{1}$, Eirini Sevdali ${ }^{3}$, Matthaios Speletas ${ }^{3}$, Maria loannou ${ }^{4}$, George K. Koukoulis ${ }^{4}$, Yves Renaudineau ${ }^{5,6^{* *}}$, George N. Dalekos ${ }^{1,2^{* *}}$

${ }^{*}$ These authors contributed equally to this work

${ }^{\star \star}$ These authors contributed equally to this work as senior authors

${ }^{1}$ Department of Medicine and Research Laboratory of Internal Medicine, National Expertise Center of Greece in Autoimmune Liver Diseases, General University Hospital of Larissa, 41110 Larissa, Greece; 'Institute of Internal Medicine and Hepatology, 41447 Larissa, Greece; ${ }^{3}$ Department of Immunology and Histocompatibility, Faculty of Medicine, School of Health Sciences, University of Thessaly, Larissa, Greece; ${ }^{4}$ Department of Pathology, Faculty of Medicine, School of Health Sciences, University of Thessaly, Larissa, Greece; 5INSERN U1291, CNR U5051, University Toulouse III, Toulouse Institute for infectious and inflammatory diseases, Toulouse, France; ${ }^{6}$ Department of Immunology, Purpan University Hospital Toulouse, Toulouse, France

\section{All correspondence and reprint requests to:}

George N. Dalekos, MD, PhD

Professor of Medicine

Head, Department of Medicine and Research Laboratory of Internal Medicine National Expertise Center of Greece in Autoimmune Liver Diseases

General University Hospital of Larissa, 41110 Larissa, Greece

Tel: ++30-241-350-2285; Fax: ++30-241-350-1557

e-mail: georgedalekos@gmail.com 
Key words: Autoimmune hepatitis, epigenetics, DNA methylation, DNAmethyltransferases, ten-eleven translocation enzymes, epigenome wide association studies.

Word count: 3998

Tables and Figures: 8

Conflict of interest: none

Financial support: This research project was supported in part by a research grant from the Hellenic Association for the Study of the Liver (HASL) and the Research Committee of the University of Thessaly (No. 2466). P. Arvaniti was also supported by a research grant for rare diseases by the Federation for the Development of Internal Medicine in Europe (FDIME).

Author contributions: Study concept and design: Kalliopi Zachou, George N Dalekos, Yves Renaudineau. Acquisition of research data: Pinelopi Arvaniti, Aggeliki Lyberopoulou, Eirini Sevdali, Maria loannou. Analysis and interpretation of data: Pinelopi Arvaniti, Kalliopi Zachou, George N Dalekos, Yves Renaudineau, Matthaios Speletas, Maria loannou, George K Koukoulis. Drafting of the manuscript: Pinelopi Arvaniti, Kalliopi Zachou, George N Dalekos, Yves Renaudineau. Critical revision and editing of the manuscript: Kalliopi Zachou, George N Dalekos, Yves Renaudineau, Matthaios Speletas, George K Koukoulis.

NOTE: Preliminary results of this project have been presented as an abstract in the $18^{\text {th }}$ European Congress of Internal Medicine, Lisbon 29-31 August, 2019, the $18^{\text {th }}$ Hellenic Congress of Hepatology, Athens 11-13 September, 2020 and the $19^{\text {th }}$ Hellenic Congress of Hepatology, 6-9 May 2021. 


\section{Abstract}

Objective: $\mathrm{AlH}$ is a chronic liver disease of unknown aetiology with favourable response to immunosuppression. Little is known about the impact of methylation modifications on disease pathogenesis.

Design: 10 patients with $\mathrm{AlH}$ at diagnosis (time-point 1 ; tp1), 9 with primary biliary cholangitis (PBC) and 10 healthy controls $(\mathrm{HC})$ were investigated. 8/10 AlH patients were also investigated following biochemical remission (timepoint 2; tp2). Peripheral CD19(+)- and CD4(+)-cells were isolated to study global DNA methylation $\left(5^{\mathrm{m}} \mathrm{C}\right) /$ hydroxymethylation $\left(5^{\mathrm{hm}} \mathrm{C}\right)$ by ELISA and mRNA of DNA methylation (DNMT1/3A/3B)/hydroxymethylation enzymes (TET1/2/3) by quantitative RT-PCR. Epigenome wide association study (EWAS) was performed in CD4(+)-cells (Illumina HumanMethylation 850K array) in $\mathrm{AlH}$ and $\mathrm{HC}$. Differences in total $5^{\mathrm{m} C} \mathrm{C} 5^{\mathrm{hm}} \mathrm{C}$ state between $\mathrm{AlH}$-tp1 and $\mathrm{HC}$ were also assessed by immunohistochemistry (IHC) on paraffin embedded liver sections.

Results: Reduced TET1 and increased DNMT3A mRNA levels characterized CD19(+) and CD4(+) lymphocytes from AlH-tp1 patients compared to $\mathrm{HC}$ and PBC respectively, without affecting global DNA $5^{\mathrm{m}} \mathrm{C} / 5^{\mathrm{hm}} \mathrm{C}$. In AlH-tp1, CD4(+) DNMT3A expression was negatively correlated with serum $\lg G(p=0.03)$. In remission (AlH-tp2), DNMT3A decreased in both CD19(+) and CD4(+)-cells $(p=0.02, p=0.03$, respectively). EWAS in CD4(+)-cells from AlH patients confirmed important modifications in genes implicated in immune responses (HLA-DP, TNF, InRNAs and CD86). IHC confirmed increased $5^{\mathrm{hm}} \mathrm{C}$ staining of periportal infiltrating lymphocytes in AlH-tp1.

Conclusion: Altered expression of TET1 and DNMT3A, characterizes peripheral immune cells in AlH. DNMT3A is associated with disease activity and decreased following therapeutic response. Gene specific DNA methylation modifications affect immunologic pathways that may play an important role in AlH pathogenesis.

\section{Words: 249}




\section{Summary box}

What is already known?

Autoimmune hepatitis $(\mathrm{AIH})$ is a non-resolving chronic liver disease of unknown aetiology and favourable response to immunosuppression. Since the interplay between the genetic background and the environment seems to be fundamental for AlH pathogenesis, epigenetic modifications may be of particular importance.

What are the new findings?

We found characteristic alterations of DNA methylation in peripheral immune cells of AlH patients, which were associated with disease activity and modified by immunosuppressive treatment.

How might it impact on clinical practice in the foreseeable future?

These results provide the first evidence that epigenetics play a role in $\mathrm{AlH}$ pathogenesis, which may have therapeutic implications for the management of the disease. 


\section{Introduction}

Autoimmune hepatitis $(\mathrm{AlH})$ is a chronic liver disease characterized by hypergammaglobulinaemia, autoantibodies, interface hepatitis and favourable response to immunosuppression (1-6). Although its aetiology remains unknown, the interaction between genetic and environmental factors seems fundamental in AlH pathogenesis $(2,3,6)$.

Genetic predisposition to $\mathrm{AlH}$ has been linked to genes within the human leucocyte antigen (HLA) region, particularly with the allelic variants $H L A$ $D R B 1{ }^{*} 0301$ and $D R B 1{ }^{*} 0401$ of DRB1, while weaker associations have been found with non-HLA genes $(7,8)$. However, $H L A D R B 1^{*} 0301$ and $D R B 1{ }^{*} 0401$ genotypes associations occur in only $51-55 \%$ of patients among different ethnicities, age groups and geographic regions, indicating that additional factors, such as epigenetic changes, could contribute to its pathogenesis $(7,9)$.

Epigenetic modifications, consisting of DNA methylation, histone adjustment and micro-RNAs (miRNAs), influence gene expression without altering the DNA sequence. In eukaryotic cells, DNA methylation represents the central epigenetic process and refers to the methylation of carbon 5 of cytosine $\left(5^{\mathrm{m}} \mathrm{C}\right)$ at the cytosine-phosphate-guanine dinucleotides (CpGs) by DNA methyltransferases (DNMT1,3A,3B) (10-12). The latter is counterbalanced by an active DNA demethylation process comprising of the oxidization of $5^{\mathrm{m}} \mathrm{C}$ into 5hydroxymethylcytosine $\left(5^{\mathrm{hm}} \mathrm{C}\right)$ by Ten Eleven Translocation $(\mathrm{TET} 1,2,3)$ deoxygenases (13).

Epigenetic studies have been performed mainly in liver fibrosis, non-alcoholic fatty liver disease, hepatocellular carcinoma and cholangiocarcinoma $(14,15)$. To date, only few studies investigated the epigenetic changes in autoimmune liver diseases. In primary biliary cholangitis (PBC), hypomethylation of several gene promoters, especially within the $\mathrm{X}$ chromosome, has been documented (16-18). Additionally, different expressions of several miRNAs have been reported in PBC and primary sclerosing cholangitis (19-22). In AIH, epigenetic data is even more limited, with only one study reporting significant association of elevated miR21 with the biochemical and histological activity of $\mathrm{AlH}$ and decreased miR21 and miR122 in cirrhotic patients (23). 
medRxiv preprint doi: https://doi.org/10.1101/2021.07.01.21259836; this version posted July 5, 2021. The copyright holder for this preprint

As from the best of our knowledge, DNA $5^{\mathrm{m} C} / 5^{\mathrm{hm}} \mathrm{C}$ have not been explored in $\mathrm{AlH}$, we investigated the potential presence of DNA methylation modifications in peripheral $\mathrm{B}$ - and T-cells from AlH patients by assessing alterations in DNA methylation through the analysis of global $5^{\mathrm{m} C}$ and DNMT1/3A/3B expression as well as alteration in $5^{\mathrm{hm}} \mathrm{C}$ and TETs transcriptional expression levels. Such analysis was performed at diagnosis and remission. Differences in total $5^{\mathrm{m}} \mathrm{C} / 5^{\mathrm{hm}} \mathrm{C}$ state between $\mathrm{AlH}$ patients at diagnosis and healthy controls $(\mathrm{HC})$ were also assessed by immunohistochemistry (IHC) on paraffin embedded liver sections. Finally, in an attempt to evaluate the methylation alterations in specific CpG sites across the whole genome, we performed epigenome wide association study (EWAS) in CD4(+)-cells from patients and controls using the Illumina HumanMethylation 850K array.

\section{Patients and Methods}

Study samples and peripheral mononuclear cells (PBMCs) preparation

PBMCs from $10 \mathrm{AlH}$ patients were isolated from peripheral blood collected at the time of diagnosis (AlH time-point 1; AlH-tp1), by gradient centrifugation (Histopaque-1077, Sigma-Aldrich, St. Louis, MI, USA). PBMCs were then mixed with freezing medium (FBS with 10\% DMSO Sigma-Aldrich) and cryopreserved in liquid nitrogen until use.

In eight of these patients, PBMCs were also isolated at a second time-point when they had complete biochemical response under immunosuppression (AlH time-point 2; AlH-tp2). According to the guidelines of the Hellenic Association for the Study of the Liver (5) and our published protocols $(24,25)$, AlH-tp2 patients were receiving at the time of investigation either combination therapy with prednisolone $0.5-1 \mathrm{mg} / \mathrm{kg} / \mathrm{day}$ and mycophenolate mofetil 1.52g/day (MMF; $n=6)$ or MMF maintenance monotherapy $(n=2)$. Ten healthy served as $\mathrm{HC}$ and $9 \mathrm{PBC}$ patients at diagnosis before treatment initiation served as the disease control group. Patients and controls were age- and sexmatched (Supplementary Table 1).

As in our previous reports $(24,25)$, all biopsies were assessed using the Knodell histologic/activity index score (26) and patients were divided into two groups according to inflammation: minimal-mild and moderate-severe and 
according to fibrosis: minimal/mild-moderate and severe fibrosis-cirrhosis. In PBC, the Ludwig staging system was applied (27).

All patients consented to participate in this study. The ethical committee of the General University Hospital of Larissa approved the protocol which conforms to the ethical guidelines of the 1975 Declaration of Helsinki as reflected in a priori approval by the institution's human research committee (21-032016/2258).

CD19(+) B- and CD4(+) T-cells isolation

CD19(+) and CD4(+)-lymphocytes were isolated by ROBOSEPTM_S platform (Stemcell Technologies, Vancouver, USA). CD19(+) B- and CD4(+) T-cells were incubated with specific antibodies for magnetic selection using the EasySep Human CD19 Positive Selection Kit II and Human CD4 Negative Selection Kit, respectively (Stemcell Technologies). Purity of the isolated Band T-cells was assessed by flow cytometry using PE-Cy5-anti-CD19 and FITC-anti-CD3/PE-anti-CD8 antibody (Biolegend Inc., San Diego, CA, USA) on a Coulter FC-500 flow cytometer (Beckman-Coulter, Brea, CA, USA) (Supplementary Figures 1A-1D). A total average of $1 \times 10^{6} \mathrm{CD} 19(+)$ and $2 \times 10^{6}$ CD4(+)-cells were isolated per sample and stored at $-80^{\circ} \mathrm{C}$.

\section{DNA/RNA extraction and quantification}

Genomic DNA was extracted from CD19(+) and CD4(+)-cells with QIAamp Blood mini purification kit (Qiagen, Hilden, Germany). Quantification was measured at 260nm in a UV-VIS Nanodrop spectrophotometer (Thermo Fisher Scientific, Waltham, MA, USA). DNA purity was determined by the ratio of $260 \mathrm{~nm}$ to $280 \mathrm{~nm}$ absorbance levels. Approximately, $0.5-1 \mu \mathrm{g}$ of genomic

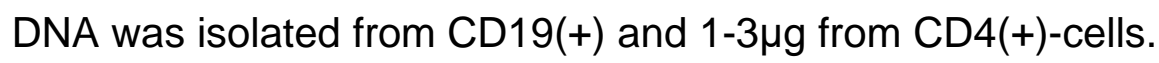

Total RNA was isolated using the RNeasy mini kit (Qiagen) and quantification and purity were determined as described above. Approximately $0.5-1.2 \mu \mathrm{g}$ of total RNA was isolated from CD19 (+) and 1-3.2ug from CD4(+)-cells.

Determination of $5^{\mathrm{m}} \mathrm{C}$ and $5^{\mathrm{hm}} \mathrm{C}$ DNA levels $5^{\mathrm{m} C}$ and $5^{\mathrm{hm}} \mathrm{C}$ DNA levels were determined using MethylFlash ${ }^{\mathrm{TM}}$ Global DNA Methylation (5-mC) and Hydroxymethylation (5-hmC) ELISA Easy Kit 
medRxiv preprint doi: https://doi.org/10.1101/2021.07.01.21259836; this version posted July 5, 2021. The copyright holder for this preprint

(EpiGentek, NY, USA), according to the manufacturer's instructions (Supplementary Patients and Methods).

DNMT1, DNMT3A, DNMT3B, TET1, TET2 and TET3 mRNA quantification One $\mu \mathrm{g}$ of total RNA was reversed transcribed using random hexamer primers and 10 Units of Transcriptor Reverse Transcriptase according to the Transcriptor First Strand cDNA synthesis kit (Roche Diagnostics, Basel, Switzerland) in a $20 \mu \mathrm{l}$ reaction for $10 \mathrm{~min}$ at $25^{\circ} \mathrm{C}, 60 \mathrm{~min}$ at $50^{\circ} \mathrm{C}$ and $5 \mathrm{~min}$ at $85^{\circ} \mathrm{C}$. Quantitative polymerase chain reaction was carried out using FastStart DNA Master SYBR Green I (Roche Diagnostics) in a total volume of $20 \mu \mathrm{l}$ containing 250nM specific forward and reverse primers. Amplification and detection were performed in a Lightcycler ${ }^{R} 96$ Instrument (Roche Life Sciences, Bavaria, Germany) under the following conditions: 1 cycle at $50^{\circ} \mathrm{C}$ for $2 \mathrm{~min}$ and $95^{\circ} \mathrm{C}$ for $10 \mathrm{~min}$ and 40 cycles at $95^{\circ} \mathrm{C}$ for $15 \mathrm{sec}$ and $60^{\circ} \mathrm{C}$ for $1 \mathrm{~min}$. The primers used for DNMT3A, DNMT3B, TET1 and TET2 were as previously described (28). For the quantification of human DNMT1, TET3 and Glyceraldehyde-3-Phosphate Dehydrogenase (GAPDH) genes, commercially specific primers were used: DNMT1: Hs00945875_m1, TET3: Hs00896441_m1, GAPDH: Hs02758991_g1 (Thermo Fisher Scientific, Waltham, MA, USA). Human GAPDH mRNA was chosen as internal control and for quantification of gene expression the comparative CT method [2- $(\Delta \mathrm{CT}$ target $-\Delta \mathrm{CT}$ calibrator) or 2- $\Delta \Delta \mathrm{CT}]$ was used. Validation experiments were carried out in duplicates and each run was completed with a melting curve analysis to confirm the specificity of the amplification and the lack of primer dimmers.

\section{EWAS}

Five hundred ng of DNA from CD4(+)-lymphocytes from AIH (10 tp1 and 5 tp2) and $9 \mathrm{HC}$ were bisulfite-converted (Zymo Research, Irvine, California, USA) and DNA methylation was evaluated by hybridising bisulfite-converted DNA to the Human Methylation EPIC array Bead Chip (Diagenode SA, Belgium), which allows the interrogation of over 850000 methylation sites throughout the genome at single-nucleotide resolution (Supplementary Patients and Methods; EWAS). These steps were performed by NXT-DX Company (Gent, Belgium) according to manufacturer's instructions. 
Methylation data was provided as $\beta$-values: $\beta=M /(M+U)$, where $M$ was the fluorescent signal of methylation and $U$ the respective signal of the unmethylated probe. The $\beta$-values ranged from 0 (no methylation) to 1 (100\% methylation). A quality control on the output of the Illumina Infinium EPIC array was performed with the Bioconductor $\mathrm{R}$ package, Chip Analysis Methylation Pipeline (ChAMP), according to which no sample had a proportion of failed probes $>0.1$. After normalisation, potential batch effects were evaluated with the singular value decomposition method, which did not identify any significant source of variations that needed corrections.

\section{Liver immunohistochemistry (IHC)}

Paraffin embedded sections from 6 AlH-tp1 patients and $7 \mathrm{HC}$ obtained during cholecystectomy, were investigated. Staining for $5^{\mathrm{m}} \mathrm{C}$ and $5^{\mathrm{hm}} \mathrm{C}$ was performed with anti-5-methylcytosine (5-mC) and anti-5hydroxymethylcytosine (5-hmC) antibodies [Abcam, 33D3 (ab10805) and RM236 (ab214728)]. 5um liver sections were deparaffinized by immersing the slides in xylene and in concentration decreasing alcohol grades solution. Antigen retrieval was performed in a Tris- EDTA $(\mathrm{pH}=9)$ solution at $98^{\circ} \mathrm{C}$ for 20 min, while endogenous peroxidase activity was blocked by quenching the tissue sections with $3.0 \%$ hydrogen peroxide in methanol for 10 minutes. The sections were then washed with $1 \%$ donkey serum in PBS-0,4\% Triton X-100 (TBST) solution for 5 minutes for permeabilization, followed by incubation with primary antibody (dilution 1/150) in room temperature for 30 minutes. After washing the sections with TBST solution, they were incubated with Linker and Polymer HRP (Ready to use reagent, Envision Flex, Dako) for 15 and 30 minutes, respectively. Finally, sections were incubated with 3,3'diaminobenzidin $\left(\mathrm{DAB}^{+}\right)$and washed with distilled water. Hematoxylin Harris was used for nuclear counterstaining and dehydration was performed in increasing concentration alcohol solutions and xylene. Negative controls consisted of substitution of primary antibody with pre-immune serum.

\section{Immunohistochemical evaluation}

Immunostaining was semi-quantitatively evaluated in a blinded fashion regarding any of the histological and clinical characteristics of the patients by 
two independent observers. The degree of staining was determined according to its amount and intensity, using a 4-point scoring system, as follows: $0=$ no staining; $1=$ positive nuclear staining in less than $20 \%$ of cells; $2=21-50 \%$ of positive cells; and $3=$ positive nuclear staining in more than $50 \%$ of cells.

\section{Statistical analysis}

Analysis was made using the SPSS 20 and GraphPad-Prism 7.0 software. Results were expressed as median (range) and mean \pm standard deviation. Data were compared with Kruskall-Wallis and Mann-Whitney U-test for the detection of differences between independent samples and Wilcoxon test for paired samples. Pearson coefficient $(R)$ and Spearman's coefficient $(r)$ were used for correlations, where applicable. Two-sided $p$-values $<0.05$ were considered as statistically significant in 95\% confidence interval.

Statistical analysis of the EWAS data was performed with the Bioconductor $\mathrm{R}$ package ChAMP (29). After normalization, identification of differentially methylated positions (DMPs) between groups was performed using Benjamini-Hochberg adjusted $p$-value $<0.05$. Differentially methylated regions (DMRs) between groups, were identified with BumpHunter method and adjusted $p$-value <0.05 (30). Gene set enrichment analysis using GOmeth method was performed on the genes associated with the DMRs to determine potential enriched pathways (31). Finally, in order to identify if differentially methylated genes shared common functional properties between $\mathrm{AlH}$-tp2 and AlH-tp1, we used the Database for Annotation, Visualization and Integrated Discovery (DAVID), which builds clusters of genes with significantly similar ontologies as tested against a complete list of genes in the database (32). Medium stringency was used to yield a broader set of ontological groups.

\section{Results}

Global $5^{\mathrm{m}} \mathrm{C}$ and $5^{\mathrm{hm}} \mathrm{C}$ in $\mathrm{CD} 19(+)$ and $C D 4(+)$-cells and their association with clinical, biochemical and serological parameters

Global $5^{\mathrm{m} C}$ and $5^{\mathrm{hm}} \mathrm{C}$ levels in CD4(+) and CD19(+)-cells did not differ between the study groups (Figure 1). In addition, $5^{\mathrm{m} C}$ and $5^{\mathrm{hm}} \mathrm{C}$ levels in $\mathrm{AlH}$ - 
medRxiv preprint doi: https://doi.org/10.1101/2021.07.01.21259836; this version posted July 5 , 2021. The copyright holder for this preprint

tp1 and AlH-tp2 patients were not correlated with age, AST, ALT, IgG, ANA and SMA (data not shown). However, $5^{\mathrm{m}} \mathrm{C}$ levels in CD4(+)-lymphocytes were negatively correlated with disease duration $(r=-0.76 ; p=0.01)$ in AlH-tp1 patients.

DNMTs and TETs in CD19(+) and CD4(+)-lymphocytes from AlH-tp1 patients AlH-tp1 patients had significantly lower TET1 mRNA levels in CD19(+) and $\mathrm{CD} 4(+)$ lymphocytes compared to $\mathrm{HC}(\mathrm{p}=0.03 ; \mathrm{p}=0.01$, respectively; Figures 2A, 2B). AlH-tp1 had significantly higher DNMT3A in CD19(+) and CD4(+) lymphocytes compared to $\mathrm{PBC}(\mathrm{p}=0.04 ; \mathrm{p}=0.002$, respectively; Figures 2C,2D). No differences of DNMT1, TET2 and TET3 in CD19(+) or CD4(+)cells were observed between $\mathrm{AlH}$-tp1 and $\mathrm{HC}$ or PBC. Of note, PBC had significantly higher DNMT1 and TET3 in CD19(+)-cells compared to HC $(p=0.02 ; p=0.005$, respectively; Supplementary Figures 2A,2B). DNMT3B levels were beyond the detection threshold so no further analysis was made.

\section{Effect of immunosuppression on DNMTs and TETs expression in AlH}

AlH-tp2 patients had significantly lower DNMT3A mRNA in CD19(+) $(p=0.02)$ and CD4(+)-lymphocytes ( $\mathrm{p}=0.03$ ) compared to AlH-tp1 (Figures 3A,3B). This supports that immunosuppression controls DNMT3A overexpression as DNMT3A levels in AlH-tp2 did not differ from HC, either in CD19(+) or in CD4(+) lymphocytes (Supplementary Figure 3). The mRNA levels of DNMT1 and TETs did not differ between the two groups (data not shown).

Association of DNMTs and TETs mRNA with clinical, biochemical and serological parameters in AlH-tp1 and AlH-tp2 patients

DNMT3A mRNA in CD4(+)- and CD19(+)-cells of AlH-tp1 was negatively correlated with $\lg G(R=-0.68 ; p=0.03$ and $R=-0.57 ; p=0.08$, respectively) (Figures 3C,3D). In contrast, DNMT3A levels in CD4(+)-cells from AlH-tp2 were positively correlated with $\lg G(r=0.8 ; p=0.02)$.

EWAS in CD4(+) lymphocytes from AlH-tp1 patients compared to $\mathrm{HC}$ As DNMT3A and TET1 mRNA variations were more important in CD4(+) as compared to $\mathrm{CD} 19(+)$ lymphocytes, $\mathrm{CD}(4+)$-cells were further selected to 
medRxiv preprint doi: https://doi.org/10.1101/2021.07.01.21259836; this version posted July 5, 2021. The copyright holder for this preprint

investigate DMRs, which are more highly associated with disease as compared to a single $\mathrm{CpG}$ analysis. To this end we have used the BumpHunter method and have identified 287 CpG motifs corresponding to 29 DMRs between $10 \mathrm{AlH}$-tp1 and $9 \mathrm{HC}$ (Figure 4A). These DMRs corresponded to unique and annotated genes present on 26 autosomes and 3 on sex chromosomes. Regarding functional genomic distribution, the majority of DMRs $(14 / 29 ; 48.3 \%)$, corresponded to gene promoters and transcription start sites (TSS), while 6/29 (20.7\%) corresponded to introns (Figure 4B). Regarding methylation status, $17 / 29$ (58.6\%) genes were hypomethylated (Table 1). Interestingly, $7 / 8$ differentially methylated genes located on chromosome 6 are located on the major histocompatibility complex (MHC). Among them, two are encoded by MHC class-II molecules: HLA-DPA1 (hypermethylated, $p=0.003$.) and HLA-DPB2 (hypomethylated, $p=0.01$ ). In addition, the long intergenic non-protein coding RNA 2571 gene (LINC02571), which belongs to the group of long noncoding RNAs (IncRNAs), was retrieved hypermethylated $(p=0.02)$, while the promoter of the tumor necrosis factor (TNF) gene was hypomethylated ( $p=0.01$; Table 1) and ZFP57 was hypermethylated $(\mathrm{p}=0.02)$.

One of the most differentially methylated genes $(p=0.0002)$ was the promoter of platelet derived growth factor receptor like gene. Finally, the $\mathrm{RhoH}$ gene was found hypermethylated ( $p=0.01$; Table 1$)$.

Using the GOmeth method, no pathways were identified as enriched based on the genes associated with the identified DMR.

\section{EWAS in CD4(+) lymphocytes from AlH-tp1 patients compared to AlH-tp2}

Next, we investigated whether methylation of the CpG motifs is affected by immunosupression in CD4(+) lymphocytes from $\mathrm{AlH}(10 \mathrm{AlH}-\mathrm{tp} 1$ and $5 \mathrm{AlH}-$ tp2). In AlH-tp2 and at CpG level, 831 differentially methylated probes (DMPs; $11,2 \%$ hypomethylated and 88,2\% hypermethylated) were identified compared to AlH-tp1, corresponding to 576 unique and annotated genes (Figure 5A). DMPs functional genomic distribution retrieved an enrichment in intergenic regions at isolated $\mathrm{CpG}$ or open sea regions as well as in gene bodies within shores regions present up to $2 \mathrm{~kb}$ from $\mathrm{CpG}$ islands (Figures $5 B, 5 C)$. 
Although GOmeth did not reveal any enriched pathway, DAVID could categorize 376/576 genes in 12 clusters and 38 subgroups (Supplementary Table 2). The main functional annotations over-represented were those classified as "nucleotide-binding kinases", "metal-binding proteins", "phospholipid-metabolism", "motor-proteins", "membrane-proteins" ( $p<0.05$; Supplementary Table 2). Of note, the annotation cluster "immunity", comprised of genes most of which were hypermethylated in AlH-tp2 (Supplementary Table 3).

To go further in the analysis of immunosuppression on DNA methylation in CD4(+) lymphocytes, the 14 DMRs between AlH-tp1 and AlH-tp2 (Supplementary Table 4) as well as the top 25 differentially methylated genes (among genes with 2 DMPs) were explored (Table 2). DMRs surrounding promoter regions were predominantly retrieved in 9/14 (64.3\%) of AlH-tp2 compared to AlH-tp1. Among the key immune genes differentially methylated between AlH-tp2 and AlH-tp1, the activation marker CD86, the miRNA processing enzyme DROSHA and IncRNAs (LINC00211 and LINC01140) were hypermethylated in AlH-tp2 ( $<<0.05$; Table 2).

\section{$5^{m} \mathrm{C} / 5^{\text {hm }} \mathrm{C}$ staining in liver sections}

Finally, representative intense and diffuse nuclear $5^{\mathrm{hm}} \mathrm{C}$ immunohistochemical staining in the majority of the lymphocytes infiltrating the portal tract of $\mathrm{AlH}$-tp1 cases is shown in Figure 6A. In addition, strong nuclear immunoreaction was observed in the limiting plate hepatocytes and bile duct epithelial cells of $\mathrm{AlH}$ tp1 cases (Supplementary Table 5, Figure 6A). On the contrary, there was absence of positive lymphocytes in the portal tract of control cases, which also showed lack of immunoreactivity in periportal hepatocytes, and weak immunostaining of few bile duct epithelial cells (Supplementary Table 5, Figure 6B).

Hepatocytes of both AlH-tp1 and control cases showed similar nuclear $5^{\mathrm{hm}} \mathrm{C}$ and $5^{\mathrm{m}} \mathrm{C}$ immunostaining (Supplementary Table 5 and 6 , respectively). $5^{\mathrm{m}} \mathrm{C}$ staining of liver infiltrating lymphocytes showed no differences in localization and intensity between patients and controls (Supplementary Table 6). 
medRxiv preprint doi: https://doi.org/10.1101/2021.07.01.21259836; this version posted July 5,2021 . The copyright holder for this preprint (which was not certified by peer review) is the author/funder, who has granted medRxiv a license to display the preprint in perpetuity.

All rights reserved. No reuse allowed without permission.

$5^{\mathrm{m} C}$ and $5^{\mathrm{hm}} \mathrm{C}$ immunostaining of Kupffer cells showed slightly reduced scores between AlH and HC (Supplementary Tables 5 and 6). However, the number of cases studied is small to allow further interpretation. 


\section{Discussion}

To the best of our knowledge, this is the first study to evaluate the DNA methylation status in liver sections and peripheral B- and T-cells from $\mathrm{AlH}$ patients. The following points arise from the present investigation: first, altered TET1 and DNMT3A expression characterizes both CD19(+) and CD4(+)lymphocytes from AlH-tp1 patients compared to HC and PBC; second, after induction of remission, DNMT3A expression is decreased; third, in AlH-tp1 patients, DNMT3A was negatively correlated with $\lg G$, while the opposite was observed in AlH-tp2 patients; forth, although changes in DNMT3A and TET1 expression were not associated with global and major $5^{\mathrm{m}} \mathrm{C} / 5^{\mathrm{hm}} \mathrm{C}$ changes, using an EWAS approach we found however, differences of DNA methylation of specific genes in CD4(+)-lymphocytes from AlH-tp1 patients compared to $\mathrm{HC}$ and $\mathrm{AlH}$-tp2 patients; and fifth, we observed strong nuclear $5^{\mathrm{hm}} \mathrm{C}$ staining at the histological level of the periportal infiltrating lymphocytes in $\mathrm{AlH}$-tp1 compared to controls. Taken together, these findings suggest that epigenetic modifications may play an important role in AlH pathogenesis and therapeutic response.

TETs are the main enzymes involved in active DNA demethylation associated with the modification and removal of $5^{\mathrm{m}} \mathrm{C}$. In mice, it has been shown that TETs play important role in mature B-cell antibody production, but also in facilitating the in-vitro differentiation of naïve CD4(+)-cells to T-regulatory cells (T-regs) by demethylating Foxp3 enhancer CNS2, while in-vivo seem to stabilize the expression of Foxp3 in T-regs (33). Therefore, TET deficient phenotypes are characterized by reduced class switch recombination capacity and decreased Foxp3 stability (33). Our findings of decreased transcriptional expression of TET1 in CD19(+)- and CD4(+)-lymphocytes from AlH patients with active disease may reflect the abovementioned immune dysregulation. In AlH-tp1, DNMT3A expression in CD19(+)- and CD4(+)-lymphocytes was increased compared to PBC. This finding together with the increased DNMT1 and TET3 levels, which characterized CD19(+)-cells of PBC compared to HC, points to a different epigenetic profile between the two diseases. In addition, increased DNMT3A and DNMT1 transcriptional levels have been reported in CD4(+)-lymphocytes from patients with either clinically or serologically active 
systemic lupus erythematosus (SLE) (34). In SLE, both methyltransferases were inversely correlated with markers of disease activity such as, C3 complement component and anti-dsDNA antibody (34). Accordingly, we found that DNMT3A levels in active AlH were negatively associated with $\lg$, a serological marker of AlH activity. This correlation between DNMT3A mRNA levels and IgG may reflect a DNMT3A dependent plasma cell dysregulation, which increases autoantibody production as indicated by the elevated IgG values (35).

Corticosteroids administration has been reported to alter DNMT1 expression in PBMCs from SLE patients, while MMF has also been shown to induce epigenetic changes $(36,37)$. This is in accordance with our findings, as immunosuppression with MMF seems to decrease DNMT3A expression in both CD19(+)- and CD4(+)-lymphocytes. The decrease of DNMT3A in responders compared to active $\mathrm{AlH}$ together with its positive correlation with IgG in patients at remission suggests that immunosuppression probably restores the epigenetic deregulations at least in B-cells.

EWAS in CD4(+)-cells showed methylation alterations of specific genes. Actually, DMRs analysis between AIH-tp1 and $\mathrm{HC}$ revealed that most DMRs located on gene promoters indicating their potential effect on the expression of implicated genes. However, recent studies have shown that the hyper/hypomethylation of the regions downstream of promoter-TSS are also highly involved in the regulation of gene expression (38).

Methylation changes in CD4(+)-cells affected, between others, HLA-DP genes. The association of AlH with the HLA class-II alleles was retrieved from early studies, and confirmed from recent genome wide association studies (GWAS) (7,8). In this context, HLA-DP polymorphisms can modulate interactions with the invariant chain chaperone, resulting in presentation of both exogenous and endogenous antigens in CD4(+)-cells (39). In addition, ZFP57 gene was found differentially methylated. ZFP57 belongs to the Methyl-CpG Binding Zinc Finger Proteins (a large family of methyl-binding proteins) and is associated with several cellular processes including regulation of gene expression, genomic imprinting, cell signalling and transcriptional repression (40). 
medRxiv preprint doi: https://doi.org/10.1101/2021.07.01.21259836; this version posted July 5, 2021. The copyright holder for this preprint

LINC02571 gene was also found hypermethylated. Recent evidence indicates that IncRNAs play important roles in controlling the development of diverse immune cells and the mechanisms of immune cell activation (41). Of note, another gene located on MHC class-III, the TNF gene promoter, was found hypomethylated. This finding keeps up with a recent study of Bovensiepen et al (42), who found that TNF gene expression in liver-infiltrating lymphocytes was strongly upregulated and that the proportion of TNF-producing CD4(+)cells was elevated both in blood and in the liver of AlH patients compared to $\mathrm{HC}$. Among the rest of the genes found hypo/hypermethylated in AlH-tp1, $\mathrm{RhoH}$ (promoter hypermethylation) belongs to the Rho family of small GTPases and plays an important role in positive and negative thymic selection, in the functional differentiation of T-cells and in T-cell activation through TCR signalling (43). Interestingly, most of the genes (88\%) of CD4(+)cells were hypermethylated in AlH-tp2 patients, suggesting a shift in methylation profile after achievement of remission, probably towards a less activated state (37). Furthermore, some of these genes such as, ANXA1 and PYCARD are known to play diverse roles in immune responses, especially in the activation of inflammasome (44).

Among the top differentially methylated genes, CD86 encodes CD86/B7.2 molecule, which is a central costimulatory molecule mainly expressed on antigen presenting cells. However, recently it has been shown that CD86 is also expressed in humans on CD4(+)-cells in response to activation, suggesting a functional role of $B 7$ molecules in the regulation of a T-cell response (45). The hypermethylation of CD86 gene in AlH at remission could signify a central role of CD86 molecule in "switch-off" of the immunological response in AIH. Interestingly, SorCS1 promoter was found hypomethylated in $\mathrm{AlH}$ at remission. This is in line with the role of the family of Vps10p receptors in the regulation of production and exocytosis of pro-inflammatory cytokines as well as the immune functions of $\mathrm{T}$ and NK-cells during adaptive immune responses (46).

In order to explore "in situ" modifications of methylation, that might contribute to AlH molecular phenotype and might influence the methylation status of circulating immune cells, we assessed the $5^{\mathrm{m}} \mathrm{C}$ and $5^{\mathrm{hm}} \mathrm{C}$ protein expression in paraffin embedded liver sections. Interestingly, the findings confirmed the 
results of EWAS since the majority of the lymphocytes infiltrating the portal tract, and the surrounding individual periportal hepatocytes, in AlH-tp1 liver sections, were hypomethylated (stained strongly for $5^{\mathrm{hm} C}$ ) compared to $\mathrm{HC}$. Of note, periportal hepatocytes and biliary duct epithelial cells seemed to follow the same pattern of hypomethylation, pointing towards an altered methylation milieu in the liver of $\mathrm{AlH}$ patients. To our knowledge, this is the first report of the $5^{\mathrm{hm}} \mathrm{C}$ and $5^{\mathrm{m}} \mathrm{C}$ liver tissue-mapping of $\mathrm{AlH}$. These findings merit further investigation in large scale studies including a large number of liver biopsies, in order to correlate the specific cellular hypomethylation with the pathogenesis and/or the progression of the disease.

Our study has some limitations as the number of patients and controls was limited. However, the fact that we studied epigenetic modifications in pure peripheral B- and T-cells but also in liver sections, increases the reliability of our findings, as epigenetic changes are cell-type specific and studies on mixed cell populations may lead to ambiguous results.

In conclusion, we showed for the first time, that altered expression of DNMT3A and TET1, as well as altered DNA methylation of specific genes characterize immune cells in periphery and at the histological level of $\mathrm{AlH}$ patients, supporting the implication of epigenetic modifications in disease pathogenesis. Notably, epigenetic modifications were associated with disease activity and modified by immunosuppression. These findings open new insights in understanding of disease pathophysiology and may lead to novel therapeutic interventions. 
medRxiv preprint doi: https://doi.org/10.1101/2021.07.01.21259836; this version posted July 5, 2021. The copyright holder for this preprint (which was not certified by peer review) is the author/funder, who has granted medRxiv a license to display the preprint in perpetuity.

All rights reserved. No reuse allowed without permission.

Acknowledgements: This research project was supported in part by a research grant from the Hellenic Association for the Study of the Liver (HASL) and the Research Committee of the University of Thessaly (No. 2466). P. Arvaniti was also supported by a research grant for rare diseases by the Federation for the Development of Internal Medicine in Europe (FDIME). 


$\begin{array}{ll}\text { Abbreviations } & \\ 5^{\text {hm} C} & \text { 5-hydroxymethyl-cytosine } \\ 5^{\mathrm{m} C} & \text { 5-methyl-cytosine } \\ \text { AIH } & \text { Autoimmune hepatitis } \\ \text { ALT } & \text { Alanine aminotransferase } \\ \text { AMA } & \text { Antimitochondrial autoantibodies } \\ \text { ANA } & \text { Antinuclear autoantibodies } \\ \text { AST } & \text { Aspartate aminotransferase } \\ \text { DAVID } & \text { Database for Annotation, Visualization and } \\ & \text { Integrated Discovery } \\ \text { DMPs } & \text { Differentially methylated probes } \\ \text { DMRs } & \text { Differentially methylated regions } \\ \text { DNMTs } & \text { DNA methyl-transferases } \\ \text { EWAS } & \text { Epigenome wide association studies } \\ \text { GAPDH } & \text { Glyceraldehyde-3-Phosphate Dehydrogenase } \\ \text { GWAS } & \text { Genome wide association studies } \\ \text { HC } & \text { Health controls } \\ \text { HLA } & \text { Human leucocyte antigen } \\ \text { MHC } & \text { Major Histocompatibility complex } \\ \text { miRNAs } & \text { micro RNAs } \\ \text { MMF } & \text { Mycophenolate mofetil } \\ \text { NASH } & \text { Non alcoholic steatohepatitis } \\ \text { PBC } & \text { Primary biliary cholangitis } \\ \text { PBMCs } & \text { Peripheral blood mononuclear cells } \\ \text { SjS } & \text { Sjögren's syndrome } \\ \text { SLA } & \text { Soluble liver antigen } \\ \text { SLE } & \text { Systemic lupus erythematosus } \\ \text { SMA } & \text { Smooth muscle cell antibodies } \\ \text { TETs } & \text { Ten-eleven translocation deoxygenases } \\ \text { TSS } & \text { Transcription start sites } \\ \text { tp1 } & \text { time point 1 } \\ \text { tp2 } & \text { time point 2 } \\ \text { Tregs } & \text { T regulatory } \\ \text { TSS } & \text { Transcription start site } \\ \text { UTR } & \text { Untranslated region } \\ & \\ & \end{array}$


medRxiv preprint doi: https://doi.org/10.1101/2021.07.01.21259836; this version posted July 5 , 2021. The copyright holder for this preprint (which was not certified by peer review) is the author/funder, who has granted medRxiv a license to display the preprint in perpetuity.

\section{References}

1. Hennes EM, Zeniya M, Czaja AJ, Parés A, Dalekos GN, Krawitt EL, et al. Simplified criteria for the diagnosis of autoimmune hepatitis. Hepatology 2008;48:169-76.

2. Gleeson D, Heneghan MA. British Society of Gastroenterology (BSG) guidelines for management of autoimmune hepatitis. Gut 2011;60:161129.

3. Zachou K, Muratori P, Koukoulis GK, Granito A, Gatselis N, Fabbri A, et al. Review article: autoimmune hepatitis -- current management and challenges. Aliment Pharmacol Ther 2013;38:887-913.

4. European Association for the Study of the Liver. EASL Clinical Practice Guidelines: Autoimmune hepatitis. J Hepatol 2015;63:971-1004.

5. Dalekos G, Koskinas J, Papatheodoridis GV. Hellenic Association for the Study of the Liver Clinical Practice Guidelines: Autoimmune hepatitis. Ann Gastroenterol 2019;32:1-23.

6. Mack CL, Adams D, Assis DN, Kerkar N, Manns MP, Mayo MJ, et al. Diagnosis and management of autoimmune hepatitis in adults and children: 2019 practice guidance and guidelines from the American Association for the Study of Liver Diseases. Hepatology 2020;72:671722.

7. Boer YS de, Gerven NMF van, Zwiers A, Verwer BJ, Hoek B van, Erpecum KJ van, et al. Genome-wide association study identifies variants associated with autoimmune hepatitis type 1. Gastroenterology 2014; 147:443-52.e5

8. Czaja AJ, Doherty DG, Donaldson PT. Review: Genetic bases of autoimmune hepatitis. Dig Dis Sci 2002;47:2139-50.

9. Czaja AJ. Global disparities and their implications in the occurrence and outcome of autoimmune hepatitis. Dig Dis Sci 2017;62:2277-92.

10. Renaudineau Y, Youinou P. Epigenetics and autoimmunity, with special emphasis on methylation. Keio J Med 2011;60:10-6.

11. Lu Q, Renaudineau $Y$, Cha S, llei G, Brooks $W H$, Selmi $C$, et al. Epigenetics in autoimmune disorders: highlights of the 10th Sjögren's syndrome symposium. Autoimmun Rev 2010;9:627-30.

12. Arvaniti $P$, Le Dantec $C$, Charras A, Arleevskaya MA, Hedrich CM, Zachou $\mathrm{K}$, et al. Linking genetic variation with epigenetic profiles in Sjögren's syndrome. Clin Immunol 2020;210:108314.

13. Rasmussen KD, Helin K. Role of TET enzymes in DNA methylation, development, and cancer. Genes Dev 2016;30:733-50. 
medRxiv preprint doi: https://doi.org/10.1101/2021.07.01.21259836; this version posted July 5,2021 . The copyright holder for this preprint (which was not certified by peer review) is the author/funder, who has granted medRxiv a license to display the preprint in perpetuity.

14. Pirola CJ, Gianotti TF, Burgueño AL, Rey-Funes M, Loidl CF, Mallardi P, et al. Epigenetic modification of liver mitochondrial DNA is associated with histological severity of nonalcoholic fatty liver disease. Gut 2013;62:1356-63.

15. Loeffler MA, Hu J, Kirchner M, Wei X, Xiao $Y$, Albrecht $T$, et al. miRNA profiling of biliary intraepithelial neoplasia reveals stepwise tumorigenesis in distal cholangiocarcinoma via the miR-451a/ATF2 axis. J Pathol 2020;252:239-51.

16. Selmi C, Cavaciocchi F, Lleo A, Cheroni C, De Francesco R, Lombardi $\mathrm{SA}$, et al. Genome-wide analysis of DNA methylation, copy number variation, and gene expression in monozygotic twins discordant for primary biliary cirrhosis. Front Immunol 2014;5:128.

17. Lleo A, Zhang $\mathrm{W}$, Zhao $\mathrm{M}$, Tan $\mathrm{Y}$, Bernuzzi $F$, Zhu B, et al. DNA methylation profiling of the $X$ chromosome reveals an aberrant demethylation on CXCR3 promoter in primary biliary cirrhosis. Clin Epigenetics 2015;7:61.

18. Arvaniti P, Zachou K, Lyberopoulou A, Gatselis NK, Brooks WH, Dalekos GN, et al. Epigenetic modifications in generalized autoimmune epithelitis: Sjögren's syndrome and primary biliary cholangitis. Epigenomes 2019;3:15.

19. Tan $Y$, Pan $T, Y e Y, G e G$, Chen $L$, Wen $D$, et al. Serum microRNAs as potential biomarkers of primary biliary cirrhosis. PloS One 2014;9:e111424.

20. Rodrigues PM, Perugorria MJ, Santos-Laso A, Bujanda L, Beuers U, Banales JM. Primary biliary cholangitis: A tale of epigeneticallyinduced secretory failure? J Hepatol 2018;69:1371-1383.

21. Banales JM, Sáez E, Uriz M, Sarvide $S$, Urribarri $A D$, Splinter $P$, et al. Up-regulation of microRNA 506 leads to decreased $\mathrm{Cl}-/ \mathrm{HCO}-$ anion exchanger 2 expression in biliary epithelium of patients with primary biliary cirrhosis. Hepatology 2012;56:687-97.

22. Tomiyama T, Yang G-X, Zhao M, Zhang W, Tanaka H, Wang J, et al. The modulation of co-stimulatory molecules by circulating exosomes in primary biliary cirrhosis. Cell Mol Immunol 2017;14:276-84.

23. Migita K, Komori A, Kozuru H, Jiuchi $Y$, Nakamura M, Yasunami M, et al. Circulating microRNA profiles in patients with type-1 autoimmune hepatitis. Plos One 2015;10:e0136908.

24. Zachou K, Gatselis N, Papadamou G, Rigopoulou EI, Dalekos GN. Mycophenolate for the treatment of autoimmune hepatitis: prospective assessment of its efficacy and safety for induction and maintenance of remission in a large cohort of treatment-naïve patients. J Hepatol 2011;55:636-46. 
medRxiv preprint doi: https://doi.org/10.1101/2021.07.01.21259836; this version posted July 5 , 2021. The copyright holder for this preprint (which was not certified by peer review) is the author/funder, who has granted medRxiv a license to display the preprint in perpetuity.

25. Zachou K, Gatselis NK, Arvaniti P, Gabeta S, Rigopoulou El, Koukoulis GK, et al. A real-world study focused on the long-term efficacy of mycophenolate mofetil as first-line treatment of autoimmune hepatitis. Aliment Pharmacol Ther 2016;43:1035-47.

26. Knodell RG, Ishak KG, Black WC, Chen TS, Craig R, Kaplowitz N, et al. Formulation and application of a numerical scoring system for assessing histological activity in asymptomatic chronic active hepatitis. Hepatology 1981;1:431-5.

27. Ludwig J, Dickson ER, McDonald GS. Staging of chronic nonsuppurative destructive cholangitis (syndrome of primary biliary cirrhosis). Virchows Arch A Pathol Anat Histol 1978;379:103-12.

28. Charras A, Arvaniti P, Le Dantec C, Arleevskaya MI, Zachou K, Dalekos GN, et al. JAK Inhibitors suppress innate epigenetic reprogramming: A promise for patients with Sjögren's syndrome. Clin Rev Allergy Immunol 2020;58:182-193.

29. Morris TJ, Butcher LM, Feber A, Teschendorff AE, Chakravarthy AR, Wojdacz TK, et al. ChAMP: 450k chip analysis methylation pipeline. Bioinforma Oxf Engl 2014;30:428-30.

30. Jaffe AE, Murakami P, Lee H, Leek JT, Fallin MD, Feinberg AP, et al. Bump hunting to identify differentially methylated regions in epigenetic epidemiology studies. Int J Epidemiol 2012;41:200-9.

31. Geeleher P, Hartnett L, Egan LJ, Golden A, Raja Ali RA, Seoighe C. Gene-set analysis is severely biased when applied to genome-wide methylation data. Bioinforma Oxf Engl 2013;29:1851-7.

32. Dennis G, Sherman BT, Hosack DA, Yang J, Gao W, Lane HC, et al. DAVID: Database for annotation, visualization, and integrated discovery. Genome Biol 2003;4:R60.

33. Lio C-WJ, Rao A. TET Enzymes and $5 \mathrm{hmC}$ in Adaptive and Innate Immune Systems. Front Immunol 2019;10:210.

34. Balada E, Ordi-Ros J, Serrano-Acedo S, Martinez-Lostao L, Rosa-Leyva $M$, Vilardell-Tarrés M. Transcript levels of DNA methyltransferases DNMT1, DNMT3A and DNMT3B in CD4+ T cells from patients with systemic lupus erythematosus. Immunology 2008;124:339-47.

35. Barwick BG, Scharer CD, Martinez RJ, Price MJ, Wein AN, Haines RR, et al. B cell activation and plasma cell differentiation are inhibited by de novo DNA methylation. Nat Commun 2018;9:1900.

36. Yang $\mathrm{Y}$, Tang $\mathrm{Q}$, Zhao $\mathrm{M}$, Liang $\mathrm{G}, \mathrm{Wu} \mathrm{H}$, Li D, et al. The effect of mycophenolic acid on epigenetic modifications in lupus CD4+T cells. Clin Immunol 2015;158:67-76. 
37. Peters FS, Peeters AMA, Hofland LJ, Betjes MGH, Boer K, Baan CC. Interferon-gamma DNA methylation is affected by mycophenolic acid but not by tacrolimus after T-cell activation. Front Immunol 2017;8:822.

38. Anastasiadi D, Esteve-Codina A, Piferrer F. Consistent inverse correlation between DNA methylation of the first intron and gene expression across tissues and species. Epigenetics Chromatin 2018;11:37.

39. Anczurowski M, Hirano N. Mechanisms of HLA-DP Antigen processing and presentation revisited. Trends Immunol 2018;39:960-4.

40. Brandt B, Rashidiani S, Bán Á, Rauch TA. DNA methylation-governed gene expression in autoimmune arthritis. Int J Mol Sci 2019;20:5646.

41. Atianand MK, Caffrey DR, Fitzgerald KA. Immunobiology of long noncoding RNAs. Annu Rev Immunol 2017;35:177-98.

42. Bovensiepen CS, Schakat M, Sebode M, Zenouzi R, Hartl J, Peiseler M, $\mathrm{Li} \mathrm{J}$ et al. TNF-producing Th1 cells are selectively expanded in liver infiltrates of patients with autoimmune hepatitis. J Immunol 2019;203:3148-3156.

43. Dorn T, Kuhn U, Bungartz G, Stiller S, Bauer M, Ellwart J, et al. RhoH is important for positive thymocyte selection and T-cell receptor signaling. Blood 2007;109:2346-55.

44. Man SM, Kanneganti T-D. Regulation of inflammasome activation. Immunol Rev 2015;265:6-21.

45. Trzupek D, Dunstan M, Cutler AJ, Lee M, Godfrey L, Jarvis L, et al. Discovery of CD80 and CD86 as recent activation markers on regulatory T cells by protein-RNA single-cell analysis. Genome Med 2020;12:55.

46. Talbot H, Saada S, Naves T, Gallet P-F, Fauchais A-L, Jauberteau M-O. Regulatory roles of sortilin and sorLA in immune-related processes. Front Pharmacol 2018;9:1507 
Table 1: Differentially methylated genes corresponding to 29 DMRs detected in AlH-tp1 patients and healthy controls $(\mathrm{HC})$.

\begin{tabular}{|c|c|c|c|c|c|}
\hline Gene & Chromosome & Description & Location & $\begin{array}{l}\text { Methylation } \\
\text { difference } \\
\text { (AlH-tp1 vs } \\
\text { HC) }\end{array}$ & $p$ value \\
\hline CAT & $11 \mathrm{p} 13$ & catalase & promoter-TSS & 0.59 & 0.001 \\
\hline EID3 & $12 \mathrm{q} 23.3$ & $\begin{array}{l}\text { EP300 interacting inhibitor } \\
\text { of differentiation } 3\end{array}$ & promoter-TSS & $-0,65$ & 0.007 \\
\hline GOLGA3 & $12 q 24.33$ & golgin A3 & intron & -0.65 & 0.01 \\
\hline HTR2A & $13 q 14.2$ & $\begin{array}{l}\text { 5-hydroxytryptamine } \\
\text { receptor } 2 \mathrm{~A}\end{array}$ & Intergenic & -0.64 & 0.01 \\
\hline RHOJ & $14 q 23.2$ & $\begin{array}{c}\text { ras homolog family } \\
\text { member J }\end{array}$ & 5' UTR & -0.56 & 0.01 \\
\hline ADAM21P & $14 q 24.2$ & $\begin{array}{c}\text { ADA } \\
\text { metallopeptidase domain } \\
21 \text { pseudogene } 1\end{array}$ & intron & 12148 & 0.0002 \\
\hline BISPR & 19p13.11 & $\begin{array}{l}\text { BST2 interferon } \\
\text { stimulated positive } \\
\text { regulator }\end{array}$ & promoter-TSS & 0.72 & 0.004 \\
\hline TYW3 & $1 p 31.1$ & $\begin{array}{l}\text { tRNA-yW synthesizing } \\
\text { protein } 3 \text { homolog }\end{array}$ & promoter-TSS & 0.88 & 0.0004 \\
\hline PM20D1 & $1 q 32.1$ & $\begin{array}{c}\text { peptidase M20 domain } \\
\text { containing } 1 \\
\end{array}$ & promoter-TSS & -0.58 & 0.005 \\
\hline WBP2NL & $22 q 13.2$ & WBP2 N-terminal like & TTS & -0.56 & 0.01 \\
\hline PAIP2B & $2 \mathrm{p} 13.3$ & $\begin{array}{l}\text { poly }(\mathrm{A}) \text { binding protein } \\
\text { interacting protein } 2 \mathrm{~B}\end{array}$ & Intergenic & -0.47 & 0.01 \\
\hline MUC-20 & $3 q 29$ & $\begin{array}{c}\text { Mucin 20, Cell Surface } \\
\text { Associated }\end{array}$ & intron & -0.69 & 0.007 \\
\hline $\mathrm{RHOH}$ & $4 p 14$ & $\begin{array}{c}\text { ras homolog family } \\
\text { member } \mathrm{H}\end{array}$ & promoter-TSS & 0.57 & 0.01 \\
\hline STPG2 & $4 q 22.3$ & $\begin{array}{c}\text { sperm tail PG-rich repeat } \\
\text { containing } 2\end{array}$ & promoter-TSS & 0.58 & 0.02 \\
\hline EIF4E & $4 q 23$ & $\begin{array}{l}\text { eukaryotic translation } \\
\text { initiation factor } 4 \mathrm{E}\end{array}$ & promoter-TSS & -0.69 & 0.005 \\
\hline VTRNA2-1 & $5 q 31.1$ & vault RNA 2-1 & TTS & 0.64 & 0.002 \\
\hline HLA-DPA1 & $6 p 21.32$ & $\begin{array}{l}\text { major histocompatibility } \\
\text { complex class II }\end{array}$ & intron & 0.58 & 0.003 \\
\hline HLA-DPB2 & $6 p 21.32$ & $\begin{array}{l}\text { major histocompatibility } \\
\text { complex class II }\end{array}$ & intron & -0.56 & 0.01 \\
\hline LINC02571 & $6 p 21.33$ & $\begin{array}{c}\text { long intergenic non- } \\
\text { protein coding RNA } 2571 \\
\text { (MHC locus) }\end{array}$ & Intergenic & 0.54 & 0.02 \\
\hline TCF19 & $6 p 21.33$ & $\begin{array}{l}\text { transcription factor } 19 \\
\text { (MHC locus) }\end{array}$ & exon & -0.93 & 0.001 \\
\hline
\end{tabular}


medRxiv preprint doi: https://doi.org/10.1101/2021.07.01.21259836; this version posted July 5,2021 . The copyright holder for this preprint (which was not certified by peer review) is the author/funder, who has granted medRxiv a license to display the preprint in perpetuity.

All rights reserved. No reuse allowed without permission.

\begin{tabular}{|c|c|c|c|c|c|}
\hline TNF & $6 p 21.33$ & $\begin{array}{l}\text { tumor necrosis factor } \\
\text { (MHC locus) }\end{array}$ & promoter-TSS & -0.49 & 0.01 \\
\hline HCG4B & $6 p 22.1$ & $\begin{array}{l}\text { HLA complex group 4B } \\
\text { (MHC locus) }\end{array}$ & promoter-TSS & 10439 & 0.008 \\
\hline ZFP57 & $6 p 22.1$ & $\begin{array}{c}\text { ZFP57 zinc finger protein } \\
\text { (MHC locus) }\end{array}$ & Intergenic & 0.52 & 0.02 \\
\hline DDX43 & $6 q 13$ & DEAD-box helicase 43 & exon & 0.56 & 0.001 \\
\hline PDGFRL & $8 p 22$ & $\begin{array}{l}\text { platelet derived growth } \\
\text { factor receptor like }\end{array}$ & promoter-TSS & -11703 & 0.0002 \\
\hline LHX6.1 & $9 q 33.2$ & LIM Homeobox 6 & intron & -0.65 & 0.01 \\
\hline CDK16 & $\mathrm{Xp11.3}$ & $\begin{array}{c}\text { cyclin dependent kinase } \\
16\end{array}$ & promoter-TSS & -0.68 & 0.006 \\
\hline TXLNGY & Yq11.222 & $\begin{array}{l}\text { taxilin gamma } \\
\text { pseudogene }\end{array}$ & promoter-TSS & -0.59 & 0.01 \\
\hline EIF1AY & Yq11.223 & $\begin{array}{c}\text { eukaryotic translation } \\
\text { initiation factor } 1 \mathrm{~A}\end{array}$ & promoter-TSS & -0.82 & 0.001 \\
\hline
\end{tabular}

AlH-tp1, autoimmune hepatitis time-point 1; AlH-tp2, autoimmune hepatitis time-point 2; TSS: transcription start site; Methylation difference between AlH-tp1 and HC: negative value means hypomethylation. 
medRxiv preprint doi: https://doi.org/10.1101/2021.07.01.21259836; this version posted July 5, 2021. The copyright holder for this preprint (which was not certified by peer review) is the author/funder, who has granted medRxiv a license to display the preprint in perpetuity.

All rights reserved. No reuse allowed without permission.

Table 2: Top 25 differentially methylated genes between AlH-tp2 and AlH-tp1 patients.

\begin{tabular}{|c|c|c|c|c|c|}
\hline Gene & $\begin{array}{l}\text { Chromo- } \\
\text { some }\end{array}$ & CpG & \begin{tabular}{|c|} 
Methylation \\
difference \\
(AlH-tp2 vs. AlH-tp1)
\end{tabular} & Description & $P$ value \\
\hline ANKRD11 & $16 q 24.3$ & $\begin{array}{l}\operatorname{cg} 00169122 \\
\operatorname{cg} 08423714\end{array}$ & $\begin{array}{l}0.07 \\
0.06\end{array}$ & Ankyrin Repeat Domain 11 & $\begin{array}{l}0.03 \\
0.04\end{array}$ \\
\hline ATP11A & $13 q 34$ & $\begin{array}{l}\text { cg16628188 } \\
\text { cg14354398 }\end{array}$ & $\begin{array}{l}-0.025 \\
0.03\end{array}$ & $\begin{array}{l}\text { ATPase Phospholipid } \\
\text { Transporting } 11 \mathrm{~A}\end{array}$ & $\begin{array}{l}0.04 \\
0.05\end{array}$ \\
\hline CARS1 & $11 \mathrm{p} 15.4$ & $\begin{array}{l}\text { cg09827966 } \\
\text { cg04137890 }\end{array}$ & $\begin{array}{l}0.03 \\
0.02\end{array}$ & Cysteinyl-TRNA Synthetase 1 & $\begin{array}{l}0.04 \\
0.05\end{array}$ \\
\hline CD86 & $3 q 13.33$ & $\begin{array}{l}\text { cg13617155 } \\
\text { cg20753131 }\end{array}$ & $\begin{array}{l}0.098 \\
0.075\end{array}$ & CD86 Molecule & $\begin{array}{l}0.04 \\
0.04\end{array}$ \\
\hline COL15A1 & 9q22.33 & $\begin{array}{l}\text { cg14259208 } \\
\text { cg07251446 }\end{array}$ & $\begin{array}{l}-0.028 \\
0.063\end{array}$ & $\begin{array}{c}\text { Collagen Type XV Alpha } 1 \\
\text { Chain }\end{array}$ & $\begin{array}{l}0.04 \\
0.04\end{array}$ \\
\hline DNAH2 & $17 p 13.1$ & $\begin{array}{l}\text { cg22573230 } \\
\text { cg26524256 }\end{array}$ & $\begin{array}{l}0.087 \\
0.02\end{array}$ & $\begin{array}{l}\text { Dynein Axonemal Heavy } \\
\text { Chain } 2\end{array}$ & $\begin{array}{l}0.04 \\
0.04\end{array}$ \\
\hline DPH6 & $15 q 14$ & $\begin{array}{l}\text { cg12382372 } \\
\text { cg26149924 }\end{array}$ & $\begin{array}{c}-0.05 \\
0.08\end{array}$ & Diphthamine Biosynthesis 6 & $\begin{array}{l}0.05 \\
0.05\end{array}$ \\
\hline DROSHA & $5 p 13.3$ & $\begin{array}{l}\text { cg15628639 } \\
\text { cg09622076 }\end{array}$ & $\begin{array}{l}-0.063 \\
0.015\end{array}$ & Drosha Ribonuclease III & $\begin{array}{l}0.03 \\
0.05\end{array}$ \\
\hline ENOX1 & $13 q 14.11$ & $\begin{array}{l}\operatorname{cg} 24171628 \\
\operatorname{cg} 10448831\end{array}$ & $\begin{array}{c}0.04 \\
0.026\end{array}$ & $\begin{array}{l}\text { Ecto-NOX Disulfide-Thiol } \\
\text { Exchanger } 1\end{array}$ & $\begin{array}{l}0.03 \\
0.04\end{array}$ \\
\hline TAF5/FAM19A5 & $22 q 13.32$ & $\begin{array}{l}\text { cg12555819 } \\
\text { cg13520744 }\end{array}$ & $\begin{array}{c}0.054 \\
0.04\end{array}$ & $\begin{array}{c}\text { FAM Chemokine Like Family } \\
\text { Member } 5\end{array}$ & $\begin{array}{l}0.04 \\
0.05\end{array}$ \\
\hline H6PD & $1 \mathrm{p} 36.22$ & $\begin{array}{l}\text { cg09021539 } \\
\text { cg13943024 }\end{array}$ & $\begin{array}{l}0.046 \\
-0.03\end{array}$ & $\begin{array}{c}\text { Hexose-6-Phosphate } \\
\text { Dehydrogenase/Glucose 1- } \\
\text { Dehydrogenase }\end{array}$ & $\begin{array}{l}0.03 \\
0.04\end{array}$ \\
\hline INPP5B & $1 p 34.3$ & $\begin{array}{l}\operatorname{cg} 01300277 \\
\operatorname{cg} 23310078\end{array}$ & $\begin{array}{c}0.063 \\
0.07\end{array}$ & $\begin{array}{c}\text { Inositol Polyphosphate-5- } \\
\text { Phosphatase B }\end{array}$ & $\begin{array}{l}0.03 \\
0.05\end{array}$ \\
\hline LINC00211 & $2 p 22.2$ & $\begin{array}{l}\text { cg12176155 } \\
\text { cg00832367 }\end{array}$ & $\begin{array}{l}0.039 \\
0.019\end{array}$ & $\begin{array}{l}\text { Long Intergenic Non-Protein } \\
\text { Coding RNA } 211\end{array}$ & $\begin{array}{l}0.009 \\
0.04\end{array}$ \\
\hline LINC01140 & $1 p 22.3$ & $\begin{array}{l}\text { cg10277282 } \\
\text { cg23492309 }\end{array}$ & $\begin{array}{l}0.06 \\
0.08\end{array}$ & $\begin{array}{l}\text { Long Intergenic Non-Protein } \\
\text { Coding RNA } 1140\end{array}$ & $\begin{array}{l}0.04 \\
0.04\end{array}$ \\
\hline LMF1 & 16p13.3 & $\begin{array}{l}\text { cg10301401 } \\
\text { cg03796797 }\end{array}$ & $\begin{array}{l}0.019 \\
0.048\end{array}$ & Lipase Maturation Factor 1 & $\begin{array}{l}0.04 \\
0.04\end{array}$ \\
\hline MAGEC2 & Xq27.2 & $\operatorname{cg} 07549474$ & 0.065 & MAGE Family Member E2 & 0.04 \\
\hline MS4A15 & $11 q 12.2$ & $\begin{array}{l}\operatorname{cg} 27474534 \\
\operatorname{cg} 01372278\end{array}$ & $\begin{array}{l}0.017 \\
0.031\end{array}$ & $\begin{array}{c}\text { Membrane Spanning 4- } \\
\text { Domains A15 }\end{array}$ & $\begin{array}{l}0.03 \\
0.04\end{array}$ \\
\hline MSRA & $8 p 23.1$ & $\begin{array}{l}\operatorname{cg} 07122519 \\
\operatorname{cg} 12712618\end{array}$ & $\begin{array}{l}0.073 \\
0.023\end{array}$ & $\begin{array}{l}\text { Methionine Sulfoxide } \\
\text { Reductase A }\end{array}$ & $\begin{array}{l}0.03 \\
0.04\end{array}$ \\
\hline PLCB1 & $20 p 12.3$ & $\begin{array}{l}\text { cg13788583 } \\
\text { cg20272813 }\end{array}$ & $\begin{array}{l}0.072 \\
0.052\end{array}$ & Phospholipase C Beta 1 & $\begin{array}{l}0.04 \\
0.03\end{array}$ \\
\hline SNORD115-15 & $15 q 11.2$ & $\begin{array}{l}\operatorname{cg} 20375947 \\
\operatorname{cg} 10963511\end{array}$ & $\begin{array}{c}0.076 \\
0.05\end{array}$ & $\begin{array}{c}\text { Small Nucleolar RNA, C/D Box } \\
115-15\end{array}$ & $\begin{array}{l}0.04 \\
0.04\end{array}$ \\
\hline ST3GAL4 & $11 \mathrm{q} 24.2$ & $\begin{array}{l}\operatorname{cg} 06534890 \\
\operatorname{cg} 08080418\end{array}$ & $\begin{array}{l}0.07 \\
0.027\end{array}$ & $\begin{array}{c}\text { ST3 Beta-GalactosideAlpha- } \\
\text { 2,3-Sialyltransferase } 4\end{array}$ & $\begin{array}{l}0.02 \\
0.04\end{array}$ \\
\hline ST6GALNAC4 & $9 q 34.11$ & $\begin{array}{l}\text { cg17139858 } \\
\text { cg20936291 }\end{array}$ & $\begin{array}{c}0.04 \\
-0.05\end{array}$ & $\begin{array}{l}\text { ST6 N-Acetylgalactosaminide } \\
\text { Alpha-2,6-Sialyltransferase } 4\end{array}$ & $\begin{array}{l}0.009 \\
0.03\end{array}$ \\
\hline STRA8 & $7 q 33$ & $\begin{array}{l}\operatorname{cg} 25778497 \\
\operatorname{cg} 15066191\end{array}$ & $\begin{array}{c}0.044 \\
0.07\end{array}$ & Stimulated By Retinoic Acid 8 & $\begin{array}{l}0.04 \\
0.04\end{array}$ \\
\hline TMEM218 & $11 \mathrm{q} 24.2$ & $\begin{array}{l}\operatorname{cg} 27596275 \\
\operatorname{cg} 19174059\end{array}$ & $\begin{array}{l}0.029 \\
0.028\end{array}$ & Transmembrane Protein 218 & $\begin{array}{l}0.04 \\
0.04\end{array}$ \\
\hline WDR27 & $6 q 27$ & $\begin{array}{l}\text { cg01393964 } \\
\text { cg04445182 }\end{array}$ & $\begin{array}{l}0.087 \\
0.036\end{array}$ & WD Repeat Domain 27 & $\begin{array}{l}0.04 \\
0.04\end{array}$ \\
\hline
\end{tabular}

AlH-tp1, autoimmune hepatitis time-point 1; AlH-tp2, autoimmune hepatitis time-point 2; CpG,

cytosine-phosphate-guanine dinucleotide 
Figure 1: No differences were found in $5^{\mathrm{m} C}$ (A and $\left.\mathbf{B}\right)$ and $5^{\mathrm{hm}} \mathrm{C}$ levels (C and D) in CD19(+) and CD4(+)-cells from AlH-tp1, AlH-tp2, PBC and HC. $5^{\mathrm{m}} \mathrm{C}, 5$-methylcytosine; $5^{\mathrm{hm}} \mathrm{C}, 5$-hydroxymethylcytosine; $\mathrm{AlH}$-tp1, autoimmune hepatitis time-point 1; AlH-tp2, autoimmune hepatitis time-point 2; PBC, primary biliary cholangitis; $\mathrm{HC}$, healthy controls; ns, not-significant.

Figure 2: A) CD19(+)-cells from AlH-tp1 characterized by reduced TET1 compared to $\mathrm{HC}(\mathrm{p}=0.03)$. B) CD4(+)-cells from AlH-tp1 characterized by reduced TET1 compared to $\mathrm{HC}(\mathrm{p}=0.01)$. $\mathrm{C})$ Increased DNMT3A was found in CD19(+)-cells from AlH-tp1 compared to PBC $(p=0.04)$. D) Increased DNMT3A was found in CD4(+)-cells from AlH-tp1 compared to PBC $(p=0.002)$. TET1, Ten-eleven translocation methylcytosine dioxygenase 1; DNMT3A, DNA methyltransferase 3A; AlH-tp1, autoimmune hepatitis timepoint 1; AlH-tp2, autoimmune hepatitis time-point 2; $\mathrm{PBC}$, primary biliary cholangitis; $\mathrm{HC}$, healthy controls.

Figure 3: $\mathrm{CD19}(+)$ and CD4(+)-cells after complete remission (AlH-tp2) characterized by decreased DNMT3A mRNA levels (logarithmic scale) compared to AlH-tp1 ( $\mathbf{A} ; p=0.02$ and $\mathbf{B} ; p=0.03)$. C) DNMT3A in CD4(+)-cells was negatively correlated with $\lg G$ in $A l H-t p 1 \quad(R=-0.68, p=0.03)$. D) $A$ negative trend was observed between DNMT3A and IgG in CD19(+)-cells from AlH-tp1 (R=-0,57, $\mathrm{p}=0.08)$. DNMT3A, DNA methyltransferase $3 \mathrm{~A} ; \mathrm{AlH}-$ tp1, autoimmune hepatitis time-point 1; AlH-tp2, autoimmune hepatitis timepoint 2.

Figure 4: A) Heatmap of significant CpGs corresponding to 29 DMRs detected between AlH-tp1 and HC (C1-C9: HC, A1-A10: AlH-tp1). B) Genomic distribution of 29 DMRs. AlH-tp1, autoimmune hepatitis time-point 1; CpGs, cytosine-phosphate-guanine dinucleotides; DMRs, differentially methylated regions; TSS: transcription start sites, IGR: intergenic regions, 5'UTR: 5'untranslated region; Hypo, hypomethylated; Hyper, hypermethylated. 
Figure 5: A) Heatmap of significant CpGs corresponding to 831 DMPs detected between AlH-tp2 $(n=5)$ and AlH-tp1 $(n=10)(R 1-5:$ AlH-tp2, A1-10: AlH-tp1). B) Genomic distribution of significant DMPs. DMPs are enriched in open sea regions and shores. C) Most DMPs are located on gene bodies and IGR. AlH-tp1, autoimmune hepatitis time-point 1; AlH-tp2, autoimmune hepatitis time-point 2; CpGs, cytosine-phosphate-guanine dinucleotides; DMPs, differentially methylated probes; TSS, transcription start sites; IGR, intergenic regions; 5'UTR, 5'untranslated region; 3'UTR, 3'untranslated region; hyper, Hypermethylated; Hypo, hypomethylated.

Figure 6: $5^{\mathrm{hm}} \mathrm{C}$ immunostaining, original magnification X200. A) AlH-tp1: $5^{\mathrm{hm}} \mathrm{C}$ immunostaining of liver tissue sections shows strong nuclear positivity in the majority of the lymphocytes infiltrating the portal tract (red arrow). Portal inflammatory infiltrate disrupts limiting plate and surrounds individual hepatocytes. The latter show nuclear immunoreaction as well (black arrow). The bile duct epithelial cells show strong immunoexpression (arrowlead). B) Controls: $5^{\mathrm{hm}} \mathrm{C}$ staining shows absence of positive lymphocytes in the portal tract. Note the absence of immunoreactivity in periportal hepatocytes. In addition, a few bile duct epithelial cells show a weaker positive immunoreaction than in $\mathrm{AlH}$. $5^{\mathrm{hm}} \mathrm{C}, 5$-hydroxymethylcytosine; AlH-tp1, autoimmune hepatitis time-point 1 . 

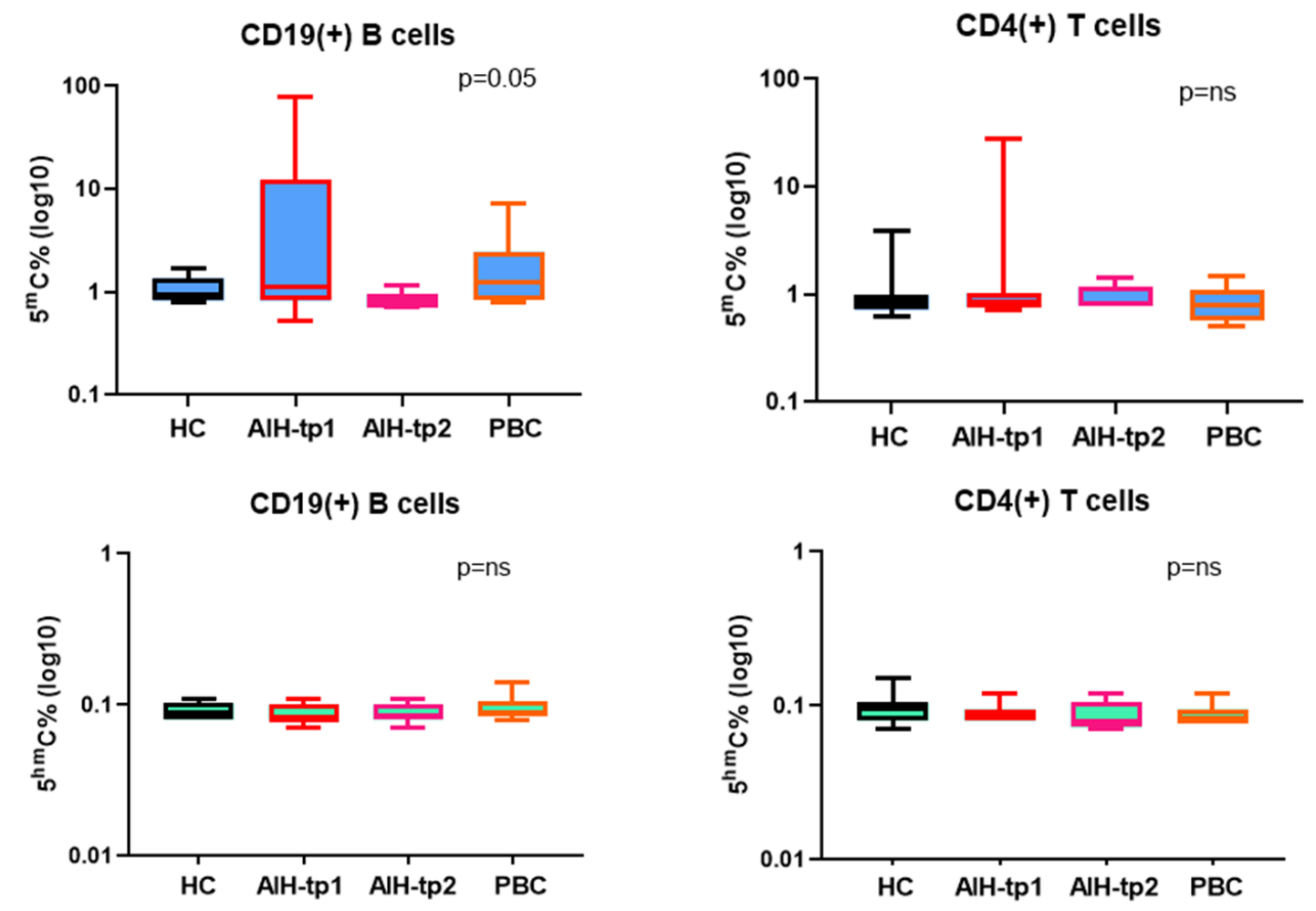

Figure 1 
TET1_CD19(+)

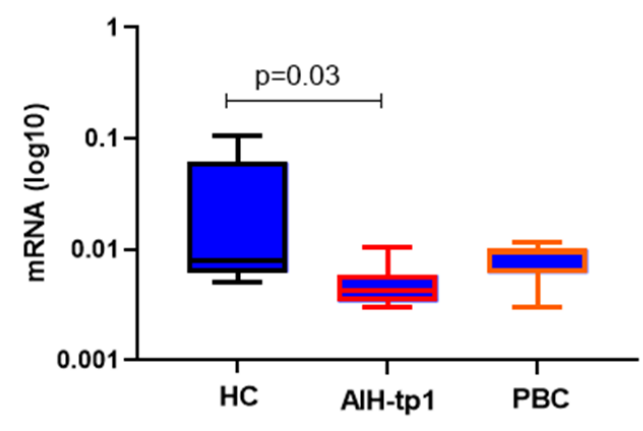

DNMT3A_CD19(+)

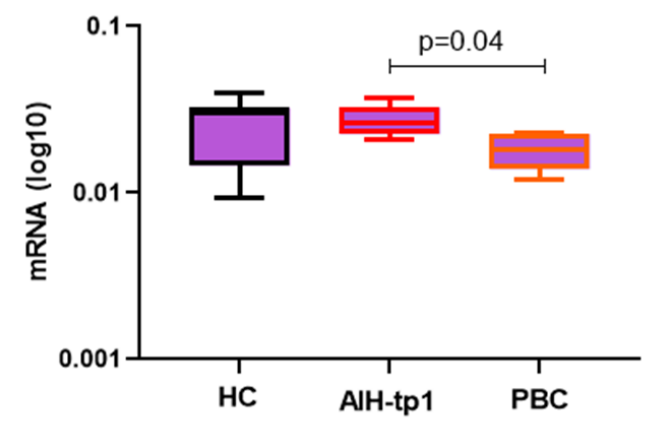

TET1_CD4(+)

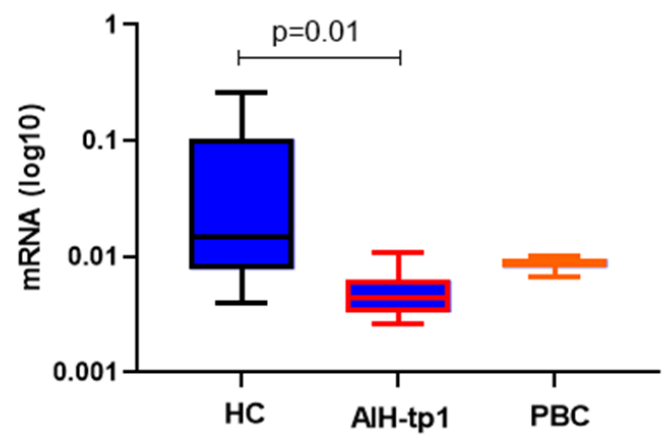

DNMT3A_CD4(+)

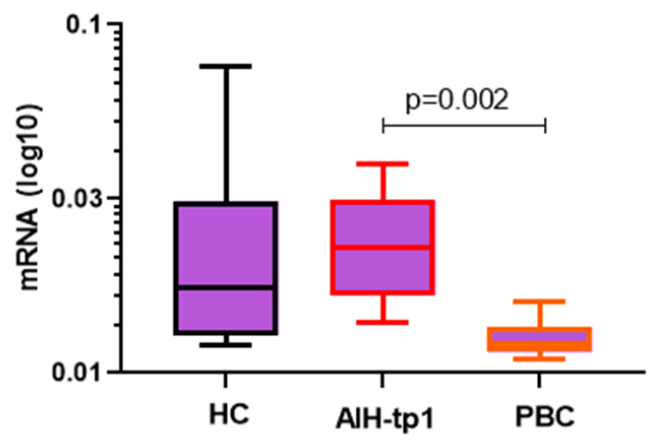

Figure 2 

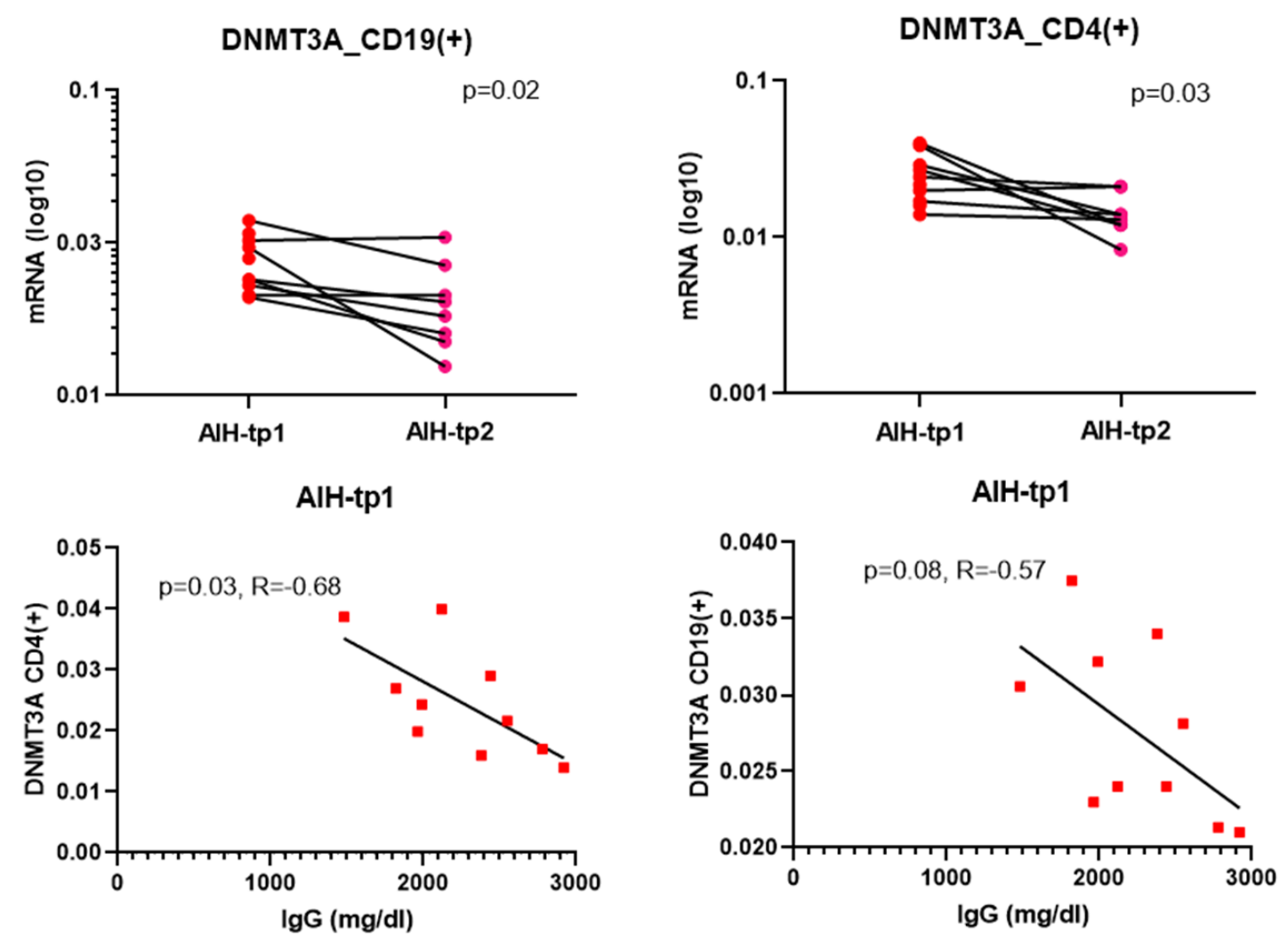

Figure 3 
medRxiv preprint doi: https://doi.org/10.1101/2021.07.01.21259836; this version posted July 5, 2021. The copyright holder for this preprint (which was not certified by peer review) is the author/funder, who has granted medRxiv a license to display the preprint in perpetuity.

All rights reserved. No reuse allowed without permission.

Heatmap for $287 \mathrm{CpGs}$ in the 29 DMRs

DMR 29-cg21863888-

DMR_28-cg01059385-

DMR 26-cg11037477-

DMR_24-cg03467027-

DMR-23-cg24266485-

DMR_21-cg01579289-

DMR_20-cg18200810 -

DMR 18-cg03817911 -

DMR_17-cg04622888 -

DMR_15-cg12667391 -

DMR_14-cg01310397-

DMR 12-cg01329005 -

DMR_11-cg12681001-

DMR 10-cg07158503-

DMR__9-cg06437840-

DMR_8-cg05621349 -

DMR_7-cg20234170-

DMR 5-cg09502221 -

DMR_4-cg15779323-

DMR_2-cg23536255-

DMR_2-cg20412244 -

DMR_1-cg20228636-

DMR_1-cg13835168-

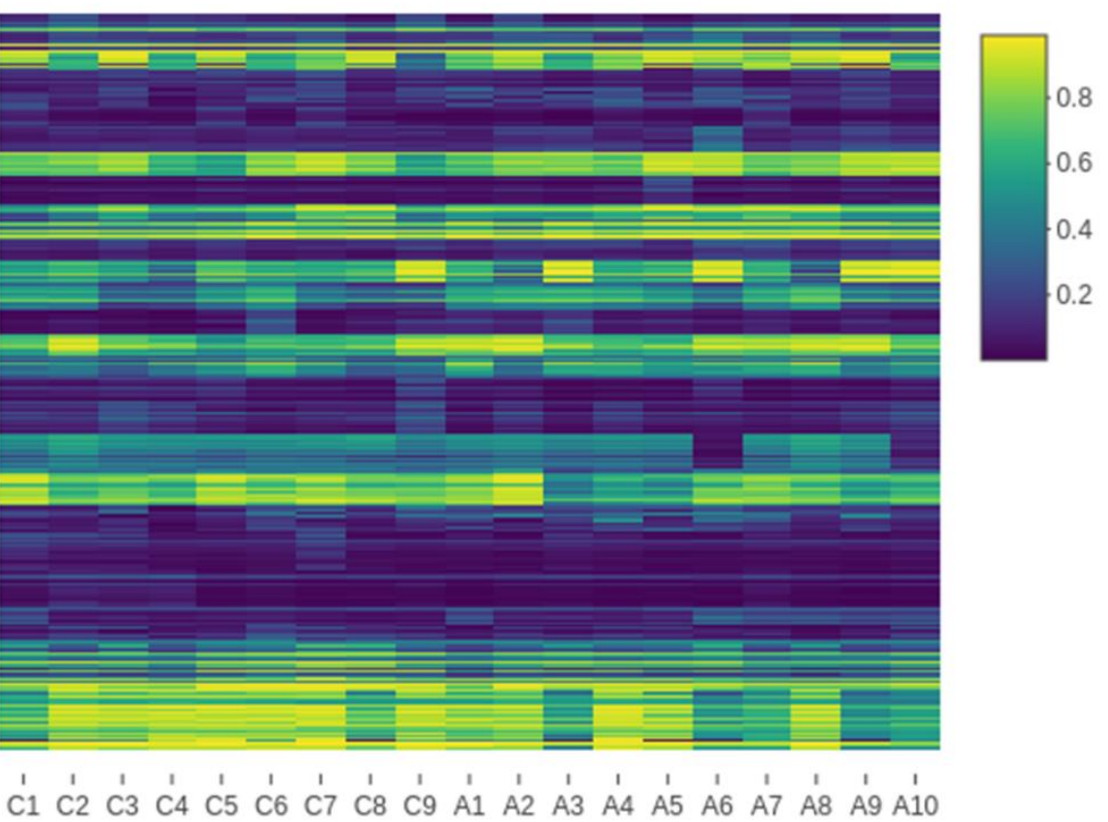

Figure 4A

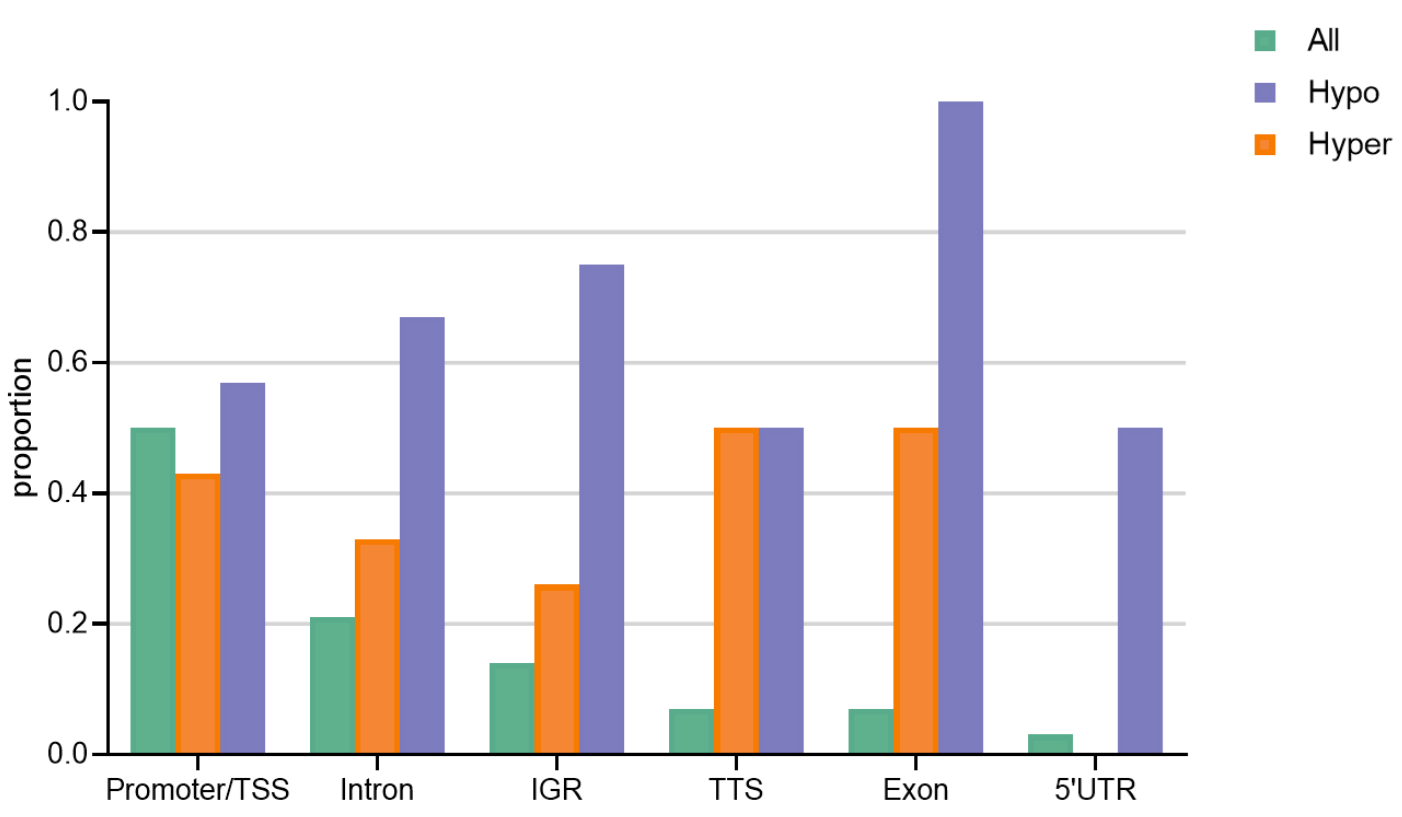

Figure 4B 
medRxiv preprint doi: https://doi.org/10.1101/2021.07.01.21259836; this version posted July 5,2021 . The copyright holder for this preprint (which was not certified by peer review) is the author/funder, who has granted medRxiv a license to display the preprint in perpetuity.

All rights reserved. No reuse allowed without permission.

Heatmap for $831 \mathrm{CpGs}$ and the respective the DMPs

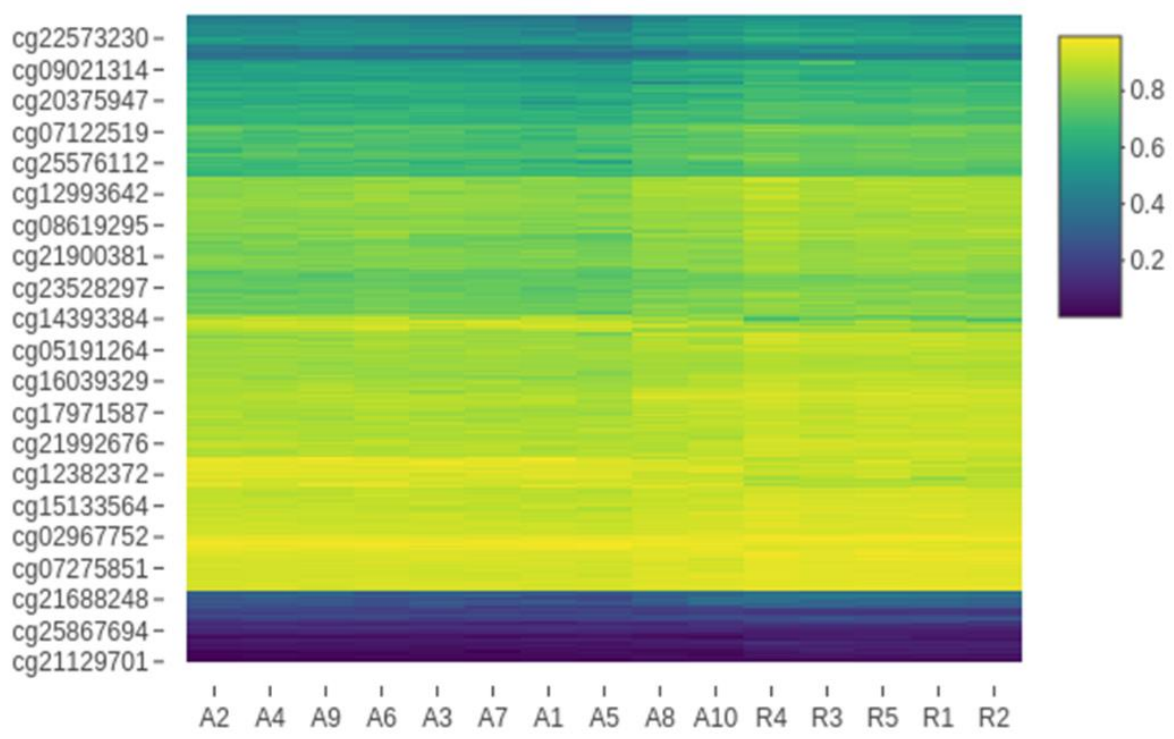

Figure 5A

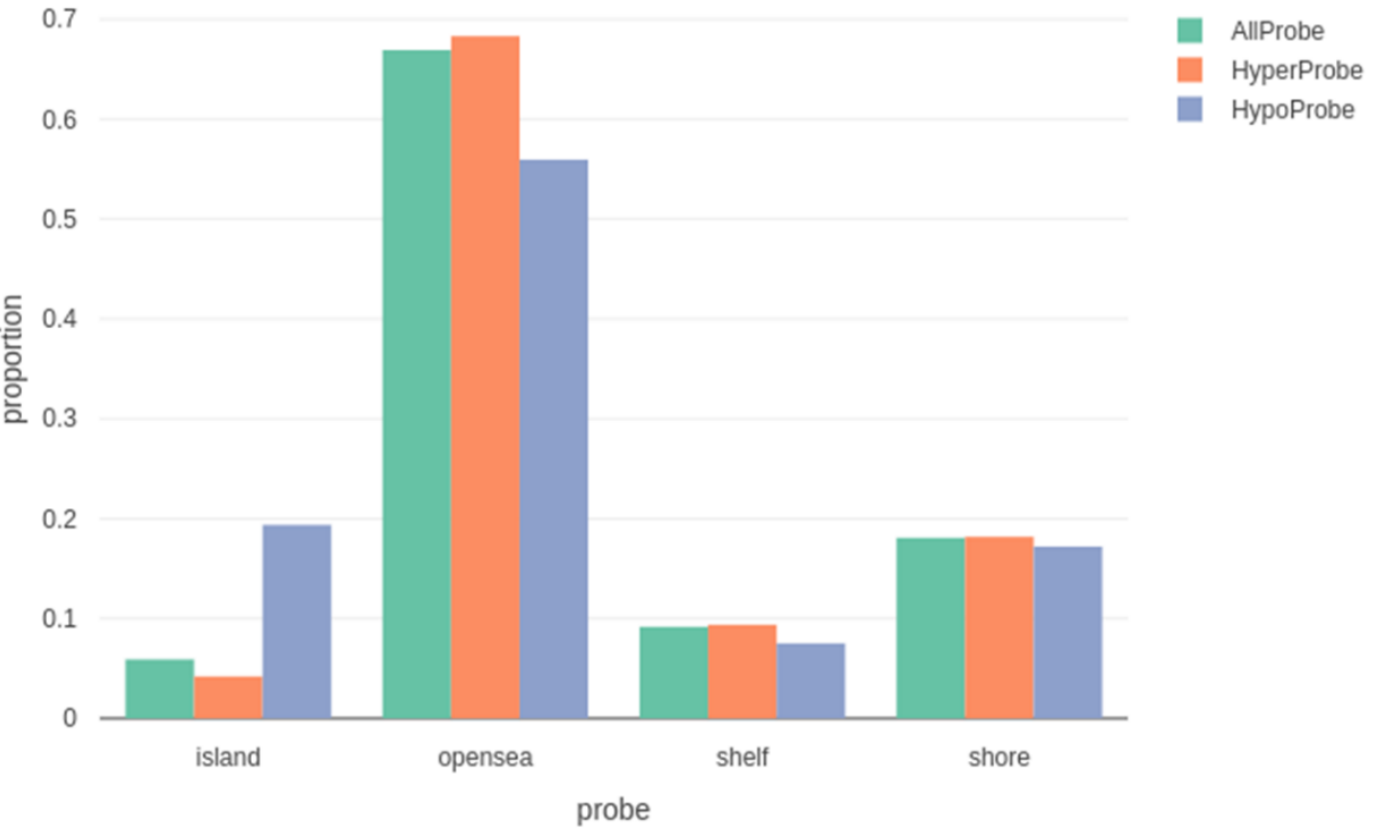

Figure 5B 
medRxiv preprint doi: https://doi.org/10.1101/2021.07.01.21259836; this version posted July 5, 2021. The copyright holder for this preprint (which was not certified by peer review) is the author/funder, who has granted medRxiv a license to display the preprint in perpetuity.

All rights reserved. No reuse allowed without permission.

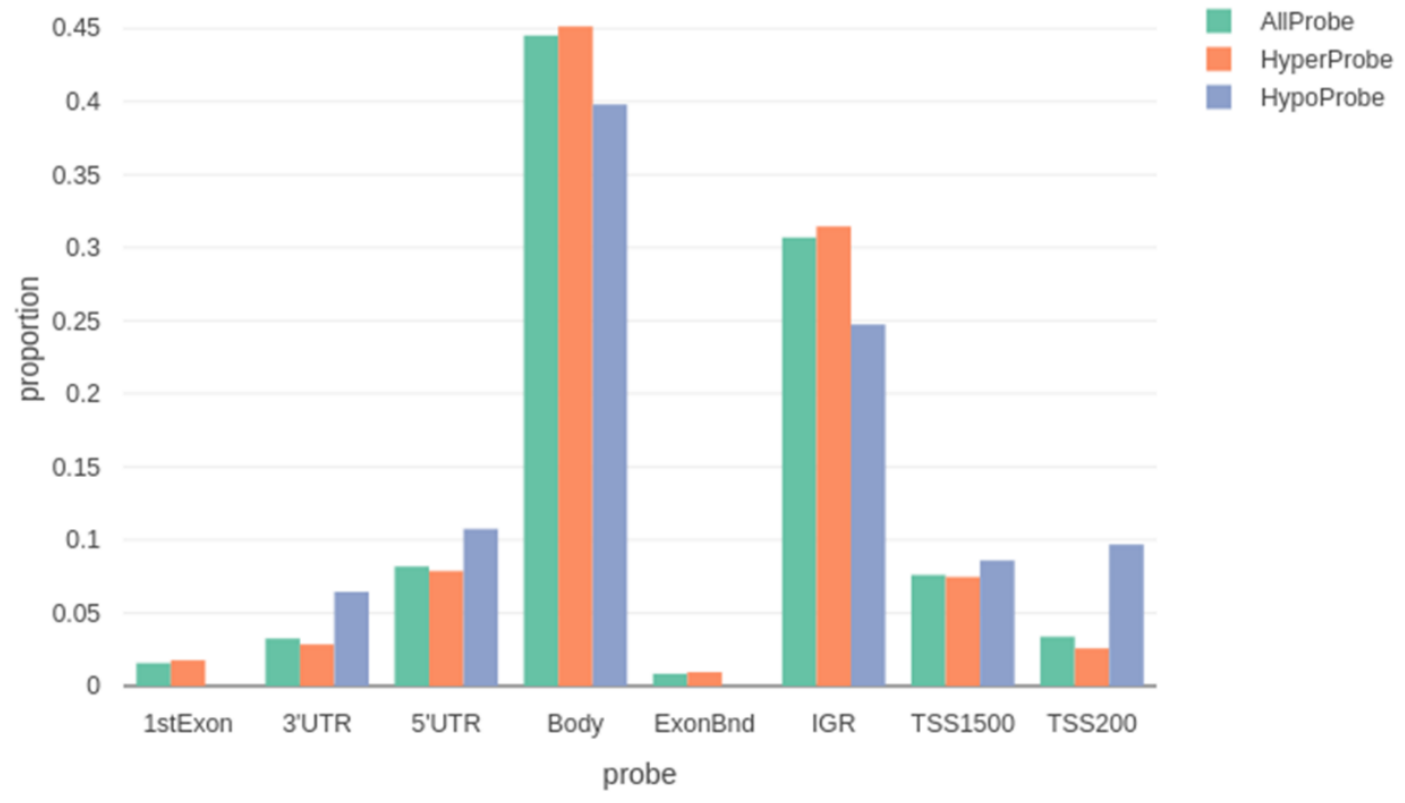

Figure 5C 
medRxiv preprint doi: https://doi.org/10.1101/2021.07.01.21259836; this version posted July 5, 2021. The copyright holder for this preprint (which was not certified by peer review) is the author/funder, who has granted medRxiv a license to display the preprint in perpetuity.

All rights reserved. No reuse allowed without permission.

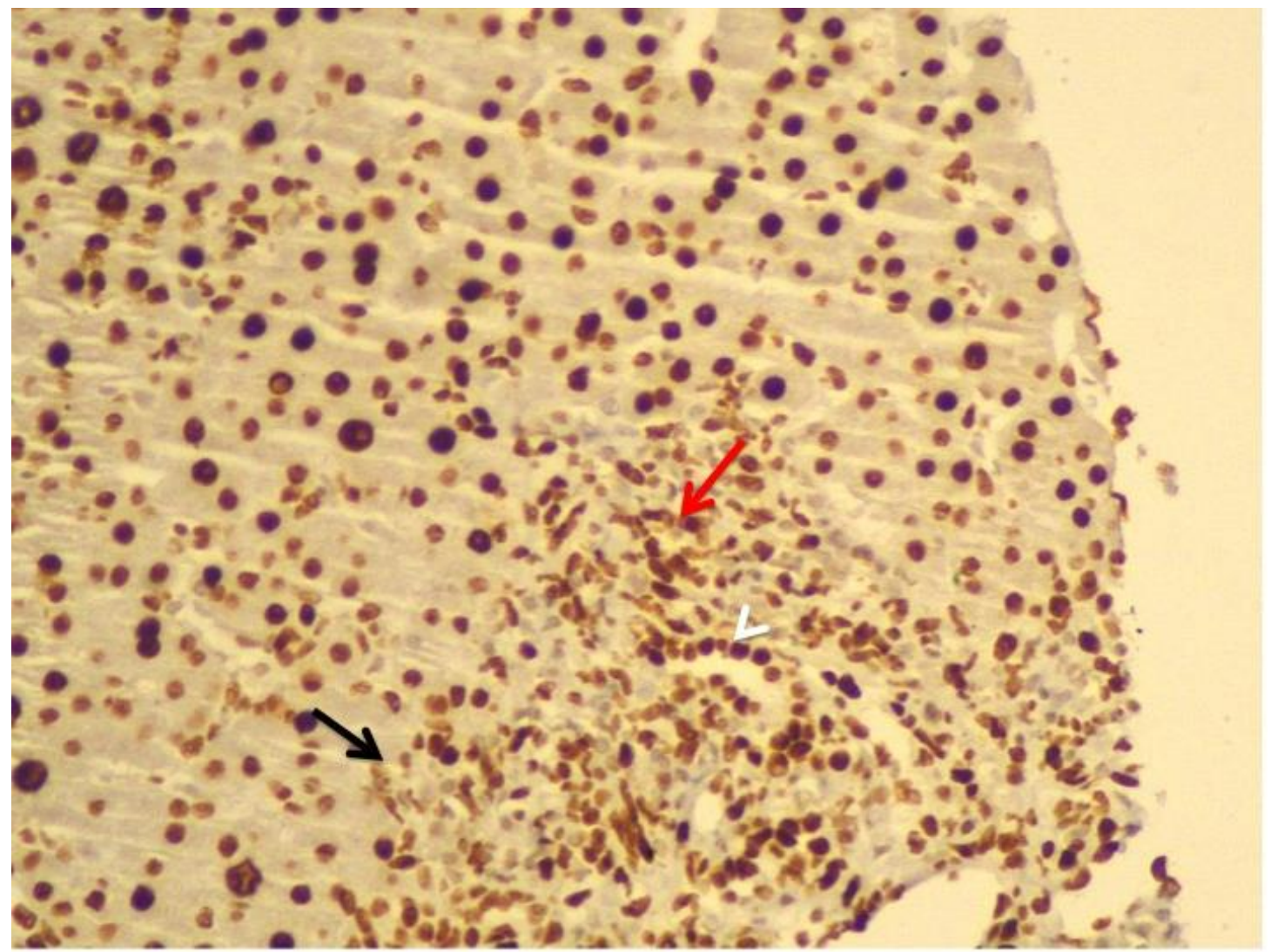

Figure 6A 
medRxiv preprint doi: https://doi.org/10.1101/2021.07.01.21259836; this version posted July 5, 2021. The copyright holder for this preprint (which was not certified by peer review) is the author/funder, who has granted medRxiv a license to display the preprint in perpetuity.

All rights reserved. No reuse allowed without permission.

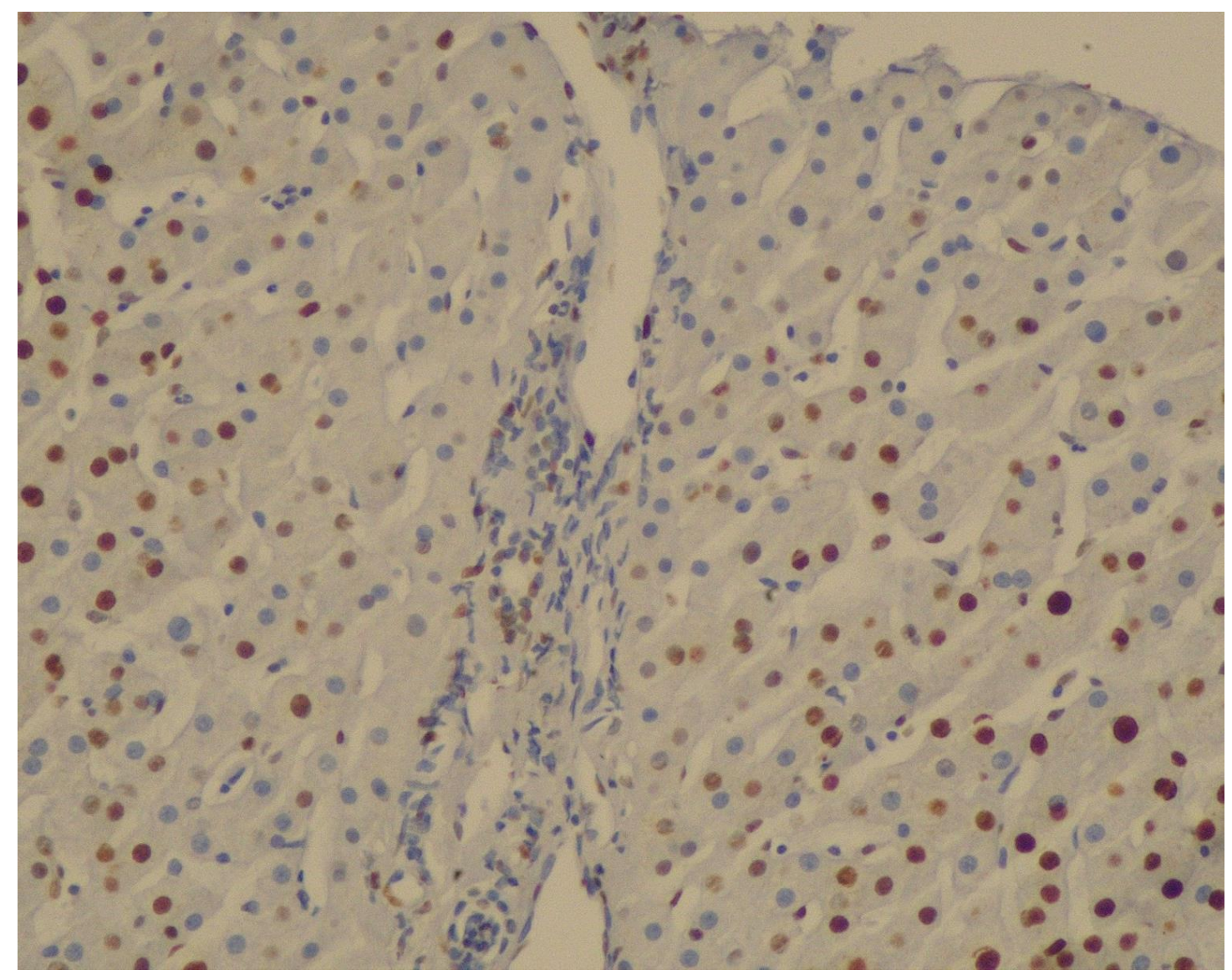

Figure 6B 